\title{
The promise of neuroprotective agents in Parkinson's disease
}

\section{Stacey E. Seidl ${ }^{1}$ and Judith A. Potashkin ${ }^{2}$.}

1 Department of Biological Sciences, DePaul University, Chicago, IL, USA

${ }^{2}$ Department of Cellular and Molecular Pharmacology, The Chicago Medical School, Rosalind Franklin University of Medicine and Science, North Chicago, IL, USA

\section{Edited by:}

Steven L. Roberds, Tuberous

Sclerosis Alliance, USA

\section{Reviewed by:}

P. Hemachandra Reddy, Oregon Health and Science University, USA

Jason B. Wu, Cedars-Sinai Medical Center, USA

\section{${ }^{*}$ Correspondence:}

Judith A. Potashkin, Department of Cellular and Molecular Pharmacology, The Chicago Medical School, Rosalind Franklin University of Medicine and Science, 3333 Green Bay Road, North Chicago, IL 60064-3037, USA.

e-mail: judy.potashkin@

rosalindfranklin.edu
Parkinson's disease (PD) is characterized by loss of dopamine neurons in the substantia nigra of the brain. Since there are limited treatment options for PD, neuroprotective agents are currently being tested as a means to slow disease progression. Agents targeting oxidative stress, mitochondrial dysfunction, and inflammation are prime candidates for neuroprotection. This review identifies Rasagiline, Minocycline, and creatine, as the most promising neuroprotective agents for PD, and they are all currently in phase III trials. Other agents possessing protective characteristics in delaying PD include stimulants, vitamins, supplements, and other drugs. Additionally, combination therapies also show benefits in slowing PD progression. The identification of neuroprotective agents for PD provides us with therapeutic opportunities for modifying the course of disease progression and, perhaps, reducing the risk of onset when preclinical biomarkers become available.

Keywords: neuroprotection, neurodegeneration, Parkinson's disease

\section{INTRODUCTION}

Parkinson's disease (PD) is a neurodegenerative disorder that results from the death of neuronal cells containing dopamine (DA) in the midbrain. Usually at the time of clinical diagnosis the patient has already lost $60 \%$ or more of the neurons in the substantia nigra pars compacta (SNpc). PD affects approximately $3 \%$ of the population over the age of 65. Most cases of PD are idiopathic and current evidence suggests that environmental factors along with a genetic susceptibility are the major causes (Lang and Lozano, 1998). Genetic forms of PD exist, but they represent less than 5\% of the cases (Langston, 1998). Oxidative stress, mitochondrial dysfunction, and inflammation play key roles in the development of PD (Michel et al., 2002; Jenner, 2003). Because a large proportion of the baby boomers are reaching the typical age of onset for $\mathrm{PD}$, there have been increased efforts to search for neuroprotective agents that will prevent the irreversible loss of neurons. In this review we summarize the current evidence that neuroprotective agents may be useful for preventing or slowing the development of PD.

\section{CAFFEINE AND NICOTINE ARE PROMISING NEUROPROTECTIVE STIMULANTS FOR PARKINSON'S DISEASE}

Most epidemiological studies support a protective benefit of drinking caffeinated beverages (Ross et al., 2000; Ascherio et al., 2001; Saaksjarvi et al., 2008), although one study showed no benefit (Xu et al., 2006). Animal studies in general also indicate that caffeine is neuroprotective. Chronic caffeine administration in mice provided protection against dopaminergic neuron toxicity from exposure to a combination of paraquat and maneb (van den Pol, 1986; Kachroo et al., 2010). In addition, acute and chronic treatment of mice with caffeine reduced the effect of acute 1methyl-4-phenyl-1,2,3,6-tetrahydropyridine (MPTP) (Chen et al., 2001) and 6-hydroxydopamine (6-OHDA) treatment on striatal DA loss (Joghataie et al., 2004). Motor dysfunctions were attenuated and DA levels increased after caffeine treatment in MPTPand 6-OHDA-treated animals (Joghataie et al., 2004; Aguiar et al., 2006). In addition, caffeine treatment partially restored noradrenaline, DA, 3,4 dihydroxyphenylacetic acid, homovanillic acid, and their metabolites in 6-OHDA-lesioned rats (Aguiar et al., 2006). Although serotonin levels decreased, levels of its metabolite, 5hydroxyindoleacetic acid, were unchanged. In treatment, the time frame of caffeine's beneficial effects is extended by its metabolites theophylline and paraxanthine, which also exert protective effects (Xu et al., 2010). An additional benefit of caffeine is that tolerance does not develop with long-term exposure (Xu et al., 2002).

The effect of estrogen on caffeine's neuroprotective capabilities is significant. Results from epidemiological studies showed improvement in male Parkinson's patients only (Ascherio et al., 2001; Costa et al., 2010). Interestingly, in post-menopausal women, caffeine consumption is also linked to a reduced risk of PD, but only among those who were not taking hormone-replacement therapy (Ascherio et al., 2003). In a follow up case-controlled study the relationships between gender, caffeine intake, estrogen, and the risk of PD were examined by investigating single nucleotide polymorphisms (SNPs) in the caffeine metabolizing genes [the cytochrome P450 (CYP) gene CYP1A2 and $N$-acetyltransferase 2 (NAT2)] and estrogen receptors (ESR1 and ESR2). A significant increased risk of PD was observed in women who had the CYP1A2 polymorphism, whereas NAT2, ESR1, and ESR2 had marginal effects on PD risk (Palacios et al., 2010). In another study, estrogen and caffeine were administered to both male and female 
MPTP-treated mice, which prevented neuroprotection in all of the animals (Xu et al., 2006). Thus, the beneficial effects of caffeine may be limited to men and post-menopausal women who are not receiving hormone-replacement therapy.

Complimentary genetic and pharmacological data from rodent studies indicate that one mechanism by which caffeine reduces dopaminergic toxicity is through antagonism of adenosine $A_{2 A}$ receptors (see review Prediger, 2010). In contrast, the indirect pathway of the basal ganglia contributes to the progression of $\mathrm{PD}$ via glutamatergic neuron overstimulation through adenosine $\mathrm{A}_{2 \mathrm{~A}}$ receptors (Bove et al., 2005b). Caffeine also activates PI3K/Akt signaling and thus reduces apoptosis (Nakaso et al., 2008).

Nicotine is comparable to caffeine with regards to lowering the risk of developing PD (Simon et al., 2009). In a Chinese epidemiological study, there was a significant reduced rate of PD in individuals who drank coffee and smoked cigarettes, which was dose-dependent (Tan et al., 2003). Toxicant responsive enzymes, including CYP1A1, CYP2E1, and glutathione $S$-transferase (GST) enzymes GST-ya, GST-yc, GSTA4-4, and vesicular monoamine transporter-2 play critical roles in modulating the protective effects of nicotine and caffeine in MPTP-treated animals (Singh et al., 2008). Interestingly, decaffeinated coffee and nicotine-free tobacco were neuroprotective in a Drosophila model of PD, but, the neuroprotection depended on the cytoprotective transcription factor nuclear factor-erythroid 2 p45-related factor 2 (Nrf2) and cafestol (an activator) (Trinh et al., 2010). This suggests that coffee and tobacco containing Nrf2-activating compounds account for the decreased risk of PD.

Nicotine without caffeine, has also shown beneficial effects in reducing the risk of $\mathrm{PD}$ in epidemiological studies and animal studies (reviewed in Quick, 2004). Animals receiving nicotine at low doses $(0.1 \mathrm{mg} / \mathrm{kg} \mathrm{s.c)}$ in vitro showed reduce DA depletion resulting from MPTP and 6-OHDA treatments (Ferger et al., 1998; Costa et al., 2001). A large dosage of nicotine $(0.4 \mathrm{mg} / \mathrm{kg} \mathrm{s.c})$, however, enhanced dopamine loss in vivo (Ferger et al., 1998). Additionally, nicotine attenuated motor deficits and nigrostriatal neurodegeneration produced by chronic administration of rotenone in mice. In 6-OHDA-lesioned rats, subchronic nicotine $(0.4 \mathrm{mg} / \mathrm{kg})$ and apomorphine treatment reduced parkinsonian contralateral rotations (Meshul et al., 2002). Chronic nicotine treatment in MPTP-treated primates restored and maintained dopaminergic function and prevented cell loss in the SNpc (Quik et al., 2006). In addition, simple exposure to tobacco smoke prior to MPTP treatment reduced the loss of striatal DA in mice (Carr and Rowell, 1990). Additionally, in humans, acute nicotine treatment can improve impaired controlled semantic processing in $\mathrm{PD}$ patients (Holmes et al., 2011). To date, nicotine is still in Phase II trials focusing on optimizing dosage and increasing sample size.

Nicotine is an alkaloid that is the predominant ingredient found in cigarettes. It has a high rate of absorption and diffuses quickly through the bloodstream and across the blood-brain barrier (BBB). Nicotine reduces the oxidative stress that is associated with the progression of $\mathrm{PD}$ by scavenging free radicals produced by monoamine oxidase-B (MAO-B), which metabolizes DA (Fowler et al., 1996; Iida et al., 1999). In addition, nicotine is capable of augmenting neurotrophic factors and cholinergic receptor expression (Ferrea and Winterer, 2009). Nicotine pretreatment attenuated the loss of dopaminergic cells in MPTP-induced mesencephalic neurons (Quik and Jeyarasasingam, 2000). Neuroprotection was blocked by a nicotine receptor antagonist suggesting the effect was mediated by nicotinic acetylcholine receptors (nAChR; Quik and Jeyarasasingam, 2000). These results suggest that the neuroprotective mechanism of nicotine may be directly or indirectly connected to the nAChR up-regulation in cerebral cortical blood flow (Linville et al., 1993). Moreover, it indicates that nAChR agonists could be beneficial in slowing the progression of PD (Maggio et al., 1997). Recently it has been suggested that stimulating nAChRs or PI3KAkt/PKB signaling could suppress dopaminergic cell death induced by rotenone (Takeuchi et al., 2009). In similar studies, nicotine induced fibroblast growth factor (FGF-2) and the brain-derived neurotrophic factor (BDNF) in the striatum (Maggio et al., 1997). Neuroprotection of DA neurons by nicotine is primarily gated by cytoplasmic $\mathrm{Ca}^{2+}$ through a mechanism involving $\alpha$-bungarotoxin-sensitive $(\alpha 7) \mathrm{nAChRs}$ and secondarily through T-type voltage-gated calcium channels (Toulorge et al., 2011).

\section{URATE AND URIC ACID HAVE MODERATE NEUROPROTECTIVE PROPERTIES}

Uric acid (UA) is a natural antioxidant that can reduce oxidative stress by acting as a scavenger of free radicals and an iron chealator (Ames et al., 1981; Davies et al., 1986; Yu et al., 1998; Hink et al., 2002). Urate suppresses oxyradical accumulation (Yu et al., 1998), inhibits cytotoxic activity of lactoperoxidase (Everse and Coates, 2004), and protects against DA-induced apoptosis (Jones et al., 2000). UA has been found to suppress oxidative stress and prevent dopaminergic cell death in animals (Duan et al., 2002). In addition, slower rates of clinical progression were observed in untreated early stage PD patients who have higher plasma, serum, and cerebrospinal fluid (CSF) concentrations of UA (Schwarzschild et al., 2008; Ascherio et al., 2009). In contrast, lower levels of urate were present in CSF (Tohgi et al., 1993) and post-mortem in the SNpc of patients with PD (Church and Ward, 1994). In a population-based cohort study of 4,695 participants aged 55 years and older, higher serum levels of UA were associated with a significantly decreased risk of PD (de Lau et al., 2005). Urate therapy reduced the risk of PD in a dose-dependent manner (de Lau et al., 2005; Schwarzschild et al., 2008). Additionally in a prospective study of subjects with early stage PD there was a $49 \%$ reduction in the progression of the disease with high urate intake (Schwarzschild et al., 2008).

Like caffeine, urate (Alonso et al., 2007) and UA (Alonso et al., 2007; Schwarzschild et al., 2008; Andreadou et al., 2009) show a gender-specific bias with a greater benefit observed in male PD patients. Epidemiological studies however contradict these results and show no gender specificity (de Lau et al., 2005; Annanmaki et al., 2007; Chen et al., 2009).

Life style choices play an important role in PD progression. Exercise, for example, decreases PD, possibly by increasing serum UA levels and decreasing excretion of UA (Schlesinger and Schlesinger, 2008). Additionally, individuals who eat diets that increase plasma urate levels have a reduced risk of PD. Dietary changes expected to increase plasma urate levels like dairy protein (but not milk) (Choi et al., 2005) and vitamin C contribute to reducing the risk of PD in men (Gao et al., 2008). These studies also 
suggest that a PD patient's diet should include adequate sources of purines, such as meat and seafood, which results in higher concentrations of UA (Annanmaki et al., 2007). Diets that result in lower UA levels could accelerate disease progression (Annanmaki et al., 2007). One must keep in mind however that a high concentration of UA in the blood serum increases the risk of gout and high alcohol and fructose consumption compounds this risk (Choi et al., 2004). Therefore, even if PD patients choose to modify their diet for potential neuroprotective effects, the physician must carefully monitor them for other at risk chronic diseases (Gao et al., 2008).

\section{VITAMIN D, BETA-CAROTENE AND RIBOFLAVIN ARE CANDIDATES FOR NEUROPROTECTIVE AGENTS}

Vitamin E ( $\alpha$-tocopherol) is a lipid-soluble antioxidant that can inhibit iron accumulation, suppress microglial activation, scavenge oxygen radicals, and prohibits the peroxidation of membrane lipids (Tappel, 1962; Burton et al., 1983; Cheeseman et al., 1988; Chow, 1991; Lan and Jiang, 1997; Li et al., 2001). Vitamin E also induces interleukin-1 $\alpha$ and tumor necrosis factor (TNF)- $\alpha$ and suppresses p38 MAPK and NFкB activation (Li et al., 2001). Vitamin $\mathrm{E}$ is regulated by $\alpha$-tocopherol transfer protein (TTP) in the liver and brain (Kaempf-Rotzoll et al., 2003). Studies have demonstrated that lack of TTP causes a systemic deficiency of vitamin E in humans and mice (Traber and Sies, 1996; Yokota et al., 2001), which can lead to enhanced oxidative stress in the brain (Yokota et al., 2001). However, vitamin $\mathrm{E}$ is also believed to reduce oxidative stress caused by iron accumulation in the brain (Lan and Jiang, 1997). Vitamin E deficiency increases MPTP toxicity in mice (Odunze et al., 1990). Vitamin E supplementation, however, had a protective effect on DA neurons in the SNpc (Roghani and Behzadi, 2001) and reduced DA loss (Lan and Jiang, 1997). Pretreatment with vitamin E was shown to reduce lipid peroxidation levels (Lan and Jiang, 1997), but depletion of striatal DA was not attenuated by pretreatment (Gong et al., 1991; Chi et al., 1992). Other studies have shown that vitamin $\mathrm{E}$ has no protective effects against DA-induced toxicity in PC12 cells (Offen et al., 1996) and only partial protection in MPTP-treated rodents (Perry et al., 1987). In addition, a genetic vitamin E deficiency did not affect MPTP susceptibility in mice (Ren et al., 2006). So either the protective effects of vitamin $\mathrm{E}$ is dependent on the mechanism by which PD is induced or high acute dose of vitamin $\mathrm{E}$ have different neuroprotective effects than chronic low doses (Fariss and Zhang, 2003; Ricciarelli et al., 2007).

There are no differences in the amount of vitamin $\mathrm{E}$ in the cerebellum (Dexter et al., 1992) or CSF (Molina et al., 1997) between PD patients and healthy individuals. Clinical trials also show no neuroprotective benefit of taking vitamin E (Fernandez-Calle et al., 1992; LeWitt, 1994; Morens et al., 1996). A meta-analysis however showed a protective effect of both moderate intake (0.67-0.98) and high intake $(0.78,0.57-1.06)$ of vitamin $\mathrm{E}$ (Etminan et al., 2005). Thus, choosing foods that are vitamin E-rich may be neuroprotective (Perlmutter, 1988; Zhang et al., 2002). The risk of PD was significantly lower in men than in women with high intake of vitamin $\mathrm{E}$ from food (Zhang et al., 2002).

Vitamin C or ascorbate, is highly concentrated in the CNS, and is associated primarily with the activity of glutamatergic neurons, which makes it a good candidate for a neuroprotector or a neuromodulator (Grunewald, 1993). Vitamin C is decreased in vascular parkinsonisms (Paraskevas et al., 2003). Results from a pilot study in which high doses of vitamin $\mathrm{E}$ and $\mathrm{C}$ were given to participants showed a decrease in $\mathrm{PD}$ progression in early stage patients (Fahn, 1992). Yet, other studies have shown few beneficial effects of vitamin $\mathrm{C}$ alone and some have shown an increase risk of PD (Scheider et al., 1997; Zhang et al., 2002; Etminan et al., 2005). In a case-controlled study of people who consumed diets rich in vitamin $\mathrm{C}$, there was a $40 \%$ risk reduction of $\mathrm{PD}$ than those consuming small amounts (Perlmutter, 1988). Because of the conflicting data, there is currently not enough data to support vitamin $\mathrm{C}$ as neuroprotective for PD.

Calcitriols are a group of fat-soluble secosteroids that include vitamin $\mathrm{D}$ and its derivatives $\mathrm{D}_{2}, \mathrm{D}_{3}, \mathrm{D}_{4}$, and $\mathrm{D}_{5}$ (Garcion et al., 2002). $D_{3}$ is obtained through the skin during sun exposure and can be ingested (Eyles et al., 2003). Vitamin D deficiency is prevalent in PD patients (Sato et al., 1997). Vitamin D receptors (DVR) in the brain are found primarily in dopaminergic neurons in the SNpc (Eyles et al., 2005) and VDR mRNA expression in the blood is a useful risk marker for identifying PD patients (Scherzer et al., 2007). Vitamin D has anti-inflammatory properties, it can regulate expression of glial cell line-derived neurotrophic factor (GDNF), and regulates calcium $\left(\mathrm{Ca}^{2+}\right)$ homeostasis (Evans, 1988; Naveilhan et al., 1996; Garcion et al., 2002; Smith et al., 2006; Chan et al., 2009; Butler et al., 2011). A disruption of $\mathrm{Ca}^{2+}$ homeostasis accelerates SNpc dopaminergic neuron loss (Butler et al., 2011). In contrast, GDNF stimulation can alleviate PD symptoms in both primate and PD patients (Gash et al., 1996; Kordower et al., 2000; Gill et al., 2003). Vitamin D was also shown to be beneficial in 6-OHDAtreated animals and in cell cultures (Wang et al., 2001; Smith et al., 2006). In addition, vitamin D increased neuromuscular function in parkinsonian rodents (Holick, 2007). In contrast to these findings, one case-controlled human study found an increased risk of PD with high consumption of vitamin D (Anderson et al., 1999). Together these findings suggest that dietary intake of vitamin D in moderate amounts may be effective in protecting individuals from PD progression although further studies are needed (Holick, 2007).

Serum levels of vitamin A are similar between, PD patients and controls suggesting that levels of vitamin A are unrelated to the risk of PD (Fernandez-Calle et al., 1992, 1993; Jimenez-Jimenez et al., 1993; Etminan et al., 2005). An epidemiological study, however, found that there was a decrease in the risk of PD in individuals who consumed foods containing carotenoids and beta-carotene (Perlmutter, 1988). Vitamin A's precursor beta-carotene, may offer neuroprotective effects by preventing lipid peroxidation (Glover, 1960; Kartha and Krishnamurthy, 1977). A recent study showed that pretreatment with beta-carotene partially protected against MPTP-induced neurotoxicity in mice (Perry et al., 1985; Yong et al., 1986), although the same was not true of primates (Perry et al., 1987).

Riboflavin, vitamin B-2, is a water-soluble vitamin present predominately in dairy products (Powers, 2003). Its biologically active forms are flavin adenine dinucleotide and flavin mononucleotide, which are electron carriers that participate in a wide range of redox reactions (Huennekens, 1956; Merrill et al., 1981). Riboflavin plays an active role in energy production and affects iron accumulation (Sirivech et al., 1977; Powers et al., 1983; Powers, 1987). The mechanism of action of riboflavin in the brain remains unknown, 
but may involve glutathione depletion, cumulative mitochondrial DNA mutations, disturbed mitochondrial protein complexes, and abnormal iron metabolism (Di Monte, 1991; Jenner et al., 1992; Logroscino et al., 1997). Riboflavin may also effect glutathione production (Perlmutter, 1988). The amount of riboflavin is lower in PD patients compared to healthy and disease controls, suggesting that taking riboflavin supplements may be beneficial (Coimbra and Junqueira, 2003). Intake of riboflavin, compared to other Bvitamins was shown to reduce the risk of PD (Murakami et al., 2010). In fact, the risk of PD was reduced $51 \%$ by users obtaining a high consumption (Perlmutter, 1988) and daily doses of riboflavin for 6 months showed improved motor capacity of PD patients in 3 months (Coimbra and Junqueira, 2003). These promising results indicate that additional longitudinal studies are needed to determine the long-term effects of chronic administration of riboflavin supplements.

\section{AMONG THE SUPPLEMENTS CREATINE SHOWS THE MOST PROMISE AS A NEUROPROTECTIVE AGENT}

Coenzyme Q10 (CoQ10), also known as ubiquinone, is a promising agent for neuroprotection in PD and other neurodegenerative diseases because of its role in the mitochondrial electron transport chain (METC) and as an antioxidant (Beal and Shults, 2003). CoQ10 serves as an electron acceptor in complex I and II of the METC. CoQ10 is protective by inhibiting SIN-1-induced apoptosis (Sharma et al., 2004), suppressing intra-mitochondrial and intra-nuclear biosynthesis of 8-OH-2dG, inhibiting translocation of caspase-3, attenuating $\alpha$-synuclein expression, and blocking intra-mitochondrial accumulation of metal ions (Ebadi et al., 2004).

Animal studies have shown that rotenone-induced parkinsonism reduced CoQ10 concentrations in plasma and the striatum with a corresponding decrease in striatal levels of DA, mitochondrial complex I activity and ATP levels, as well as significant increase in B-cell lymphoma 2 (Bcl-2) expression (Abdin and Hamouda, 2008). Administration of CoQ10 protected the nigrostriatal dopaminergic neurons in MPTP-treated mice (Shults et al., 1999). In addition, a diet containing CoQ10 (1,600 mg/kg/day, 2 months) or CoQ10 supplementation diminished neural tissue damage (Cleren et al., 2008). CoQ10 was also effective in preventing DA depletion, loss of tyrosine hydroxylase neurons and formation of $\alpha$-synuclein inclusions in the SNpc in mice (Cleren et al., 2008).

Reduced levels of CoQ10 are present in PD patients' plasma and platelets (Matsubara et al., 1991; Gotz et al., 2000) and in cortex (Hargreaves et al., 2008), which correlated with reduced activity of complex I and II/III (Shults et al., 1997, 1999). In addition, the percent of CoQ10 in its oxidized form is elevated in PD patients (Sohmiya et al., 2004). Chronic administration of CoQ10 in PD patients delays the progression of PD (Shults et al., 2002; Shults, 2003) with no adverse effects (Galpern and Cudkowicz, 2007). Additionally, CoQ10 supplements showed promising results in a small group of de novo PD patients during phase II clinical trials although no follow up study has been published (Shults et al., 2002). More recently, another human trial found inconclusive results from CoQ10 supplements in PD patients (Investigators, 2007). CoQ10 (2,400 mg/day) and vitamin E (1,200 IU/day) together initially was thought to be beneficial for PD patients (Shults et al., 2004), however, in Phase III trials it was deemed futile $\left(\mathrm{NINDS}^{1}\right)$.

Creatine is a guanidino compound found primarily in meat products and is produced endogenously by the liver, kidney, and pancreas (Tarnopolsky and Beal, 2001; Adhihetty and Beal, 2008). Creatine possesses antioxidant properties and can regulate intracellular calcium, suppress extracellular glutamate levels, and inhibit the opening of the mitochondrial permeability transition pore (MPT; Figure 1) (Xu et al., 1996; Lawler et al., 2002; Dedeoglu et al., 2003).

A combination of CoQ10 and creatine shows an additive neuroprotective effect in chronic MPTP-treated mice (Yang et al., 2009). Additionally, creatine has shown promising neuroprotective effects in combination with CoQ10 in PD patients (Yang et al., 2009). Alone, creatine protects against MPTP-induced DA depletion in the SNpc (Matthews et al., 1999). Interestingly, in a stage II clinical trial creatine showed a delay in the progression of PD by $50 \%$ compared to controls that received a placebo (Investigators, 2006). In a follow up study 18 months later, creatine continued to show efficacy as a neuroprotective agent (Investigators, 2008) and it is currently in Phase III trials (NET-PDLS ${ }^{2}$ ).

${ }^{1}$ http://www.ninds.nih.gov/disorders/clinical_trials/CoQ10-Trial-Update.htm ${ }^{2}$ http://clinicaltrials.gov/ct2/show/NCT00449865

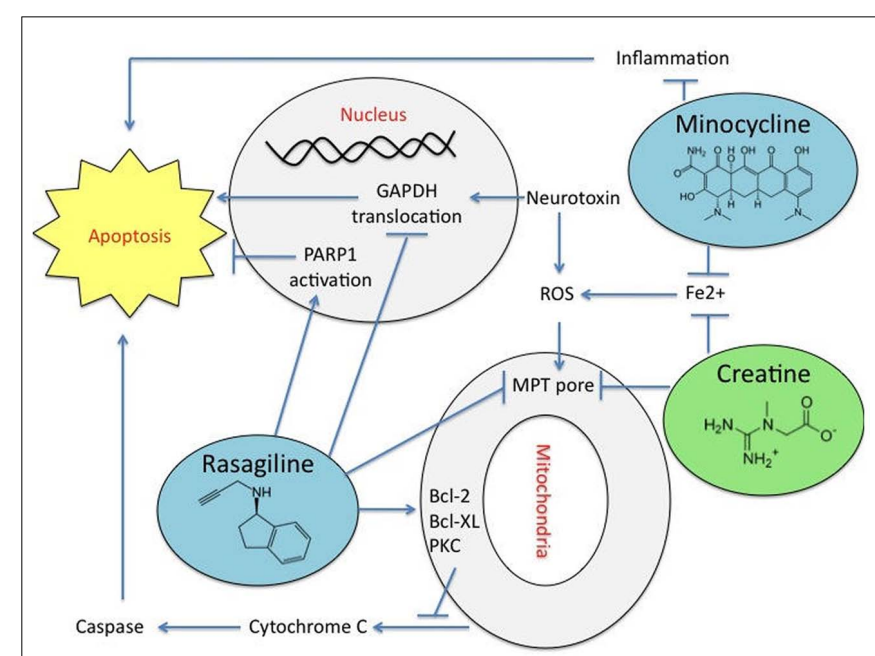

FIGURE 1 | The mechanisms of action of neuroprotective agents that are in clinical trials. Rasagiline shows neuroprotective properties by suppressing mitochondrial apoptosis stopping the mitochondrial permeability transition pore (MPT) opening by inhibiting caspase-3, nuclear poly [ADP-ribose] polymerase 1 (PARP-1) activation, stopping the translocation of glyceraldehyde-3-phosphate dehydrogenase (GAPDH), and halting nucleosomal DNA fragmentation. Rasagiline increases the expression of the anti-apoptotic proteins B-cell lymphoma $2(\mathrm{Bcl}-2)$ and $\mathrm{B}$-cell lymphoma-extra large $(\mathrm{Bcl}-\mathrm{xL})$ through the protein kinase $\mathrm{C}(\mathrm{PKC})$ pathway, in addition to down-regulating the pro-apoptotic Bcl-2-associated death promoter (Bad) and Bcl-2-associated X protein (Bax). Minocycline inhibits the inflammatory response to prevent cell death and it chealates metals. Creatine inhibits activation of the MPT and represses iron $\left(\mathrm{Fe}^{2+}\right)$ accumulation. 
Omega-3 polyunsaturated fatty acids appear to be neuroprotective for several diseases (Bousquet et al., 2011) including a small study with PD patients (da Silva et al., 2008). Animal studies have shown that the omega-3 fatty acid docosahexaenoic acid (DHA) can replace the omega-6 fatty acids already present in the brains of mice that had been given supplements after MPTP treatment (Bousquet et al., 2008). DHA is an essential factor in growth and development in the brain (Horrocks and Yeo, 1999) and has anti-inflammatory capabilities due to its ability to inhibit cyclo-oxygenase-2 (COX-2) (Massaro et al., 2006). DHA $(5-50 \mu \mathrm{g} / \mathrm{ml})$ protected neurons against cytotoxicity, inhibited both nitrogen oxide (NO) production and $\mathrm{Ca}^{2+}$ influx, and increased the activities of antioxidant enzymes of glutathione peroxidase and glutathione reductase (Wang et al., 2003) in cell cultures. DHA does not alter the levels of glutathione (GSH) (Wang et al., 2003). Animal studies showed that DHA decreased apoptosis of dopaminergic cells after MPTP treatment (Ozsoy et al., 2011). Short-term administration of DHA (100 mg/kg) reduced $40 \%$ of the levodopa-induced dyskinesias in Parkinsonian primates (Samadi et al., 2006). DHA also preserved DA levels, tyrosine hydroxylase $(\mathrm{TH})$-positive neurons and nuclear receptor related1 protein expression from MPTP-induced neurotoxicity in mice (Bousquet et al., 2008). Chronic administration of uridine and DHA increased the levels of neural phosphatides and proteins in synaptic membranes (Wurtman et al., 2006) and dendritic spines in rodents (Sakamoto et al., 2007). DHA and uridine administration also reduced parkinsonian related behaviors and elevated DA levels in 6-OHDA rats (Cansev et al., 2008). Human studies on the effects of DHA are now needed before recommendations may be made to PD patients.

DHA's proposed mechanisms of neuroprotection are linked to its anti-oxidative activity in vivo (Hashimoto et al., 2002; Yavin et al., 2002; Calon et al., 2004; Wu et al., 2004; Bazan, 2005), its ability to increase glutathione reductase activity (Hashimoto et al., 2002) and decrease the accumulation of oxidized proteins (Calon et al., 2004; Wu et al., 2004) and levels of lipid peroxide and reactive oxygen species (ROS) (Hashimoto et al., 2002, 2005). DHA also triggered inactivation of cell-signaling pathways leading to caspase activation (Calon et al., 2004, 2005) and hyperphosphorylation of tau (Green et al., 2007). In addition, DHA regulates the PI3K/Akt cascade (Akbar and Kim, 2002; Akbar et al., 2005; Kim, 2007). DHA has no association with beta-secretase or gamma-secretase complex, but it can down-regulate presenilin-1 in vitro and in vivo (Lim et al., 2005; Green et al., 2007). Other potential mechanisms of action of DHA include regulation of inflammation, gene transcription, and cell membrane properties (de Urquiza et al., 2000; Salem et al., 2001; Jump, 2002).

Melatonin has been associated with nigrostriatal protection, reduced auto-oxidation of $\mathrm{L}$-3,4-dihydroxyphenylalanine, and has antioxidant properties (Fertl et al., 1993; Miller et al., 1996; Reiter et al., 1997; Khaldy et al., 2000; Rocchitta et al., 2006). Decreased levels of melatonin are present in PD patients compared to controls (Sandyk, 1990). Melatonin's free radical scavenging properties and its ability to easily pass the BBB suggest that it may be neuroprotective (Antolin et al., 2002; see review Mayo et al., 2005).

Animal studies have shown that melatonin can prevent cell death and damage induced by MPTP (Acuna-Castroviejo et al.,
1997), 6-OHDA (Kim et al., 1998), and iron (Maharaj et al., 2006a) in neurons and astrocytes (Martin et al., 2002). Melatonin blocked apoptosis and necrosis in 6-OHDA-treated undifferentiated and nerve growth factor (NGF)-differentiated PC12 cells (Mayo et al., 1998, 1999). Contrary to these results, striatal DA depletion and DA neuron loss increased after melatonin treatment of rotenoneinduced Parkinsonism (Tapias et al., 2010). Melatonin given to PD patients improved the duration of sleep and reduced sleep disturbances (Dowling et al., 2005). There are no clinical studies to date that have investigated whether melatonin is neuroprotective for PD patients.

The antioxidant GSH, which is involved in iron metabolism and plays an ancillary role in thiol-redox control, is depleted in the SNpc of PD patients (Perry et al., 1982; Riederer et al., 1989; Pearce et al., 1997). When GSH was depleted in vitro and in vivo, there was oxidative damage of complex I proteins (Chinta and Andersen, 2006; Chinta et al., 2007; Kumar et al., 2011), defects in basal ganglia formed (Sian et al., 1994), and the ubiquitin-proteasome system functioned poorly (Martin and Teismann, 2009), but the electron transport chain complex was unaffected (Heales et al., 2011). Collectively these studies suggest that GSH may facilitate cascading events leading to oxidative stress (Bharath et al., 2002; Garrido et al., 2011).

Animal studies have also shown that excessive or reduced GSH levels can initiate degeneration of DA neurons (Garrido et al., 2011). However, chronically decreased GSH concentrations in the brain did not directly correlate to a reduction in the viability of DA neurons in the SNpc, nor decrease the number of striatal DA terminals, but does make neurons more susceptible to neurotoxins (Schulz et al., 2000). Treatment with MPTP in GSH peroxidasedeficient mice resulted in depletion of DA (Klivenyi et al., 2000). In nigral $\mathrm{TH}$ immune responsive cells similar results were seen with a greater reduction of DA neurons when lower levels of GSH were present prior to toxin administration (Pileblad et al., 1989; Seaton et al., 1996; Wullner et al., 1996). These studies suggest that the concentration of GSH is key to its neuroprotective capabilities. It has been hypothesized that enhancement of GSH synthesis or inhibition of its degradation may result in a decrease in disease progression (Schulz et al., 2000).

Phytic acid (IP6) is a naturally occurring iron chelator in food that acts by altering cell-signaling pathways and the activity or expression of antioxidant enzymes (Shamsuddin et al., 1997; Xu et al., 2011). IP6 is capable of inhibiting MPTP, 6-OHDA, and iron toxicity in cell culture (Xu et al., 2008, 2011). IP6 increases cell survival in MPTP-treated cells and repressed caspase-3 activity and DNA fragmentation (Xu et al., 2008). IP6 also suppressed hydroxyl radical formation after 1-methyl-4-phenylpyridinium (MPP+) treatment in rats (Obata, 2003). Further animal and human studies are needed to test IP6's antioxidant's properties.

\section{SEVERAL COMMONLY PRESCRIBED DRUGS ARE EMERGING AS THERAPEUTIC AGENTS FOR PD}

Common household drugs such as aspirin and Ibuprofen protect against neuro-inflammation, which can lead to neurodegeneration in the brain (Hirsch and Hunot, 2009). The use of non-steroidal anti-inflammatory drugs (NSAIDS) has been shown to lower the risk of PD in epidemiological studies (Chen et al., 2003; Ton et al., 
2006; Wahner et al., 2007; Gao et al., 2011) and protect against neuronal death, ROS/peroxidation, and dopaminergic neurotoxicity by inhibiting cyclo-oxygenase enzymes in animals (Bilodeau et al., 1995; Kaufmann et al., 1997; Aubin et al., 1998; Saini et al., 1998; Casper et al., 2000; Sairam et al., 2003). Pretreatment with NSAIDS is neuroprotective in MPTP and 6-OHDA-treated animals and in vitro (Esposito et al., 2007). In humans there was a reduction in PD risk observed in individuals who use Ibuprofen, but no reduction was found in individuals who use NSAIDS or Acetaminophen (Chen et al., 2005; Ton et al., 2006; Driver et al., 2011; Gao et al., 2011). A case-controlled study also concluded that NSAID's and aspirin show no association with altering the risk of PD (Becker et al., 2011). In some studies there was a reported increased risk of PD observed in individual who use aspirin (Bower et al., 2006; Hernan et al., 2006). In contrast, other studies showed that aspirin was protective and functioned by ROS scavenging in vivo (Di Matteo et al., 2006; Maharaj et al., 2006b). Ibuprofen protects DA neurons against glutamate toxicity and decreases MPTP toxicity in vitro (Casper et al., 2000; Morioka et al., 2004; Carrasco et al., 2005). A meta-analysis determined that regular use of Ibuprofen also reduced the risk of developing PD in humans by $40 \%$ (Samii et al., 2009; Gao et al., 2011). The results from these studies together suggest that Ibuprofen and aspirin may be neuroprotective.

The dihydropyridine L-type calcium channel blocker Isradipine has been reported to reduce hypoxia-induced activation of $\mathrm{Ca}^{2+}$-dependent xanthine oxidases, monoamine oxidases, cytosolic phospholipase $\mathrm{A}_{2}$, and cyclo-oxygenases (COX-2) along with a decrease in free radical generation and cytochrome- $c$ release (Barhwal et al., 2009). Increased expression of calpain, caspase-3, (Barhwal et al., 2009), and glutamate-induced neurotoxicity (Pizzi et al., 1991) was also inhibited by Isradipine.

The use of L-type $\mathrm{Ca}^{2+}$ channel antagonists protects SNpc DA neurons in MPTP-treated animals (Kupsch et al., 1995, 1996; Chan et al., 2007), but the same was not true of 6-OHDA-treated animals (Sautter et al., 1997). This discrepancy may be the result of the different mechanisms by which the two toxins act on mitochondria (Bove et al., 2005a). Currently very few studies specifically address Isradipine's neuroprotective capabilities, however a dosedependent effect was observed in 6-OHDA-treated animals (Ilijic et al., 2011). In a pilot study in which PD patients were treated with Isradipine no negative side effects were noted thus paving the way for further clinical testing (Simuni et al., 2010).

Because a mutation in the DJ-1 protein causes early onset of autosomal PD (Bonifati et al., 2003; Ibanez et al., 2003) and lower levels of DJ-1 are associated with PD, it is thought that drugs that up-regulate DJ-1 may slow disease progression by moderating oxidative stress and protein aggregation (Zhou et al., 2011). DJ-1 acts through multiple pathways, and works in parallel with PINK1/parkin (Zhou et al., 2011). Phenylbutyrate, a chaperone molecule and histone deacetylase inhibitor, increased DJ-1 expression in DA cell cultures, rescued cells from oxidative stress, and reduced $\alpha$-synuclein aggregation (Zhou et al., 2011). In MPTP-treated animals, phenylbutyrate protected DA neurons in the SNpc and increase DJ-1 expression (Gardian et al., 2004; Zhou et al., 2011). Long-term administration of phenylbutyrate reduced deterioration in motor and cognitive functions in mice (Zhou et al., 2011). Similar results were seen with 4-phenylbutyrate in rotenone-treated mice (Inden et al., 2007).

Type 2 diabetes has been correlated with an increase risk of PD and a high prevalence of insulin resistance has been found in PD patients, suggesting that the two chronic diseases may share similar dysregulated pathways that play a role in cell death and dysfunction (Arvanitakis et al., 2004; Jeerakathil et al., 2007). Possible shared pathways may be related to insulin regulation, suggesting that diabetes drugs may possess neuroprotective effects (Holst et al., 2011). Glucagon-like peptide-1 (GLP-1) is commonly used to treat type 2 diabetes. GLP-1 also acts as a growth factor in the brain, and can induce neurite outgrowth and protect against oxidative injury in cultured neuronal cells (Perry et al., 2007). The anti-apoptotic actions of GLP-1 is thought to be related to the activation of the transcription factor cAMP response elementbinding protein by phosphorylation (Perry et al., 2002; Li et al., 2009). Previous studies have also claimed that PDA, PI3K, and MAPK may be involved in the mechanism of action of GLP-1, in addition to MAPK-independent signaling and growth factordependent Ser/Thr kinase AktPKB (Lazaroff et al., 1995; During et al., 2003; Perry and Greig, 2005).

Exendin-4 (Ex-4), an analog of GLP-1, protected DA neurons from degeneration, preserved DA levels, and improved motor function in rodents (Li et al., 2009) by inhibiting microglial activation and matrix metalloproteinase- 3 expression (Kim et al., 2009). Ex-4 has also been shown to protect ventral mesencephalic dopaminergic cells in culture, reverse nigral lesions, and protect against 6-OHDA toxicity (Harkavyi et al., 2008; Li et al., 2009). Ex-4 receptors also show neuroprotection by mediating and increasing neurogenesis in the subventricular zone in rodents (Bertilsson et al., 2008). In addition to Ex-4, other analogs of GLP1 offer promising neurprotective effects (see review Harkavyi and Whitton, 2010). One of these, Liraglutide, has been shown to be neuroprotective in an Alzheimer's disease model (McClean et al., 2010, 2011).

\section{RASAGILINE AND MINOCYCLINE ARE CURRENTLY IN CLINICAL TRIALS AS NEUROPROTECTIVE AGENTS FOR PD}

Rasagiline is a selective and potent propargylamine MAO-B inhibitor (Tatton et al., 2003), that reduces MPTP and 6-OHDA toxicity in PC12 and SH-SY5Y cells, (Maruyama et al., 2000) and is neuroprotective in vivo (Heikkila et al., 1985; Huang et al., 1999; Speiser et al., 1999; Sagi et al., 2001; Youdim et al., 2001a). Pretreatment with Rasagiline prevents nigrostriatal damage induced by MPTP in primates (Kupsch et al., 2001; Sagi et al., 2001). Chronic administration of Rasagiline increased DA neuron survival in lesioned SNpc and improved motor impairments (Blandini et al., 2004). Rasagiline also increased the expression of the neurotrophins BDNF, GDNF, and NGF (Murer et al., 2001). In humans, Rasagiline reduced the long-term progression and symptoms in PD (Hauser et al., 2009; Olanow et al., 2009). In a promising recent study, Rasagiline delayed the need for antiparkinsonian drugs and patients had lower scores on the PD rating scale in a Phase III study (Rascol et al., 2011).

Rasagiline suppresses mitochondrial apoptosis by inhibiting caspase-3 and nuclear poly [ADP-ribose] polymerase 1 
Table 1 | Neuroprotective agents in PD models.

\begin{tabular}{|c|c|c|c|c|}
\hline \multirow{2}{*}{$\begin{array}{l}\text { Neuroprotective } \\
\text { agents }\end{array}$} & \multicolumn{2}{|c|}{ Cell culture and animal studies } & \multicolumn{2}{|c|}{ Human and epidemiological studies } \\
\hline & Study & Results & Study & Results \\
\hline \multirow[t]{3}{*}{ Caffeine } & $\begin{array}{l}\text { A (van den Pol, 1986; } \\
\text { Kachroo et al., 2010) }\end{array}$ & $\begin{array}{l}\text { Decreased dopaminergic neuron } \\
\text { toxicity in MPTP }\end{array}$ & $\begin{array}{l}\text { E (Ross et al., 2000; Ascherio } \\
\text { et al., 2001)*, (Saaksjarvi et al., } \\
\text { 2008; Costa et al., 2010)* }\end{array}$ & $\begin{array}{l}\text { Caffeinated beverages } \\
\text { decreased the risk of PD }\end{array}$ \\
\hline & $\begin{array}{l}\text { A (Joghataie et al., 2004; } \\
\text { Aguiar et al., 2006) }\end{array}$ & $\begin{array}{l}\text { Decreased motor dysfunctions in } \\
6-O H D A\end{array}$ & H (Ascherio et al., 2003) & $\begin{array}{l}\text { A decrease in PD risk among } \\
\text { women consuming caffeine } \\
\text { and not taking hormone- }\end{array}$ \\
\hline & A (Xu et al., 2002, 2010) & $\begin{array}{l}\text { Caffeine increased metabolites } \\
\text { associated with prevention of DA } \\
\text { loss }\end{array}$ & & replacement therapy \\
\hline $\begin{array}{l}\text { Caffeine }+ \\
\text { nicotine }\end{array}$ & A (Trinh et al., 2010) & $\begin{array}{l}\text { Decaffeinated coffee and } \\
\text { nicotine-free tobacco were } \\
\text { neuroprotective in Drosophila }\end{array}$ & E (Tan et al., 2003) & $\begin{array}{l}\text { Caffeine and nicotine com- } \\
\text { bined reduced the rate of PD }\end{array}$ \\
\hline \multirow[t]{2}{*}{ Nicotine } & $\begin{array}{l}\text { A (Ferger et al., 1998; } \\
\text { Costa et al., 2001) } \\
\text { A (Meshul et al., 2002) }\end{array}$ & $\begin{array}{l}\text { Nicotine reduced DA depletion } \\
\text { resulting from MPTP and 6-OHDA } \\
\text { Nicotine minimized parkinsonian } \\
\text { contralateral rotations in 6-OHDA }\end{array}$ & $\begin{array}{l}\text { E (Quick, 2004; Simon et al., } \\
\text { 2009) }\end{array}$ & $\begin{array}{l}\text { Nicotine lowered the risk of } \\
\text { developing PD }\end{array}$ \\
\hline & A (Quik et al., 2006) & $\begin{array}{l}\text { Non-human primates maintained } \\
\text { dopaminergic function and cell } \\
\text { loss in the SNpc was prevented } \\
\text { with nicotine administration }\end{array}$ & & \\
\hline & & & H (Ascherio et al., 2009) & $\begin{array}{l}\text { Slower rates of clinical pro- } \\
\text { gression of PD were seen } \\
\text { with UA intake }\end{array}$ \\
\hline & & & $\begin{array}{l}\text { H (de Lau et al., 2005; } \\
\text { Schwarzschild et al., 2008) }\end{array}$ & $\begin{array}{l}\text { Serum UA correlates with a } \\
\text { decreased risk of PD }\end{array}$ \\
\hline \multirow[t]{5}{*}{ Vitamin E } & A (Odunze et al., 1990) & $\begin{array}{l}\text { Vitamin E deficiency increases } \\
\text { MPTP toxicity }\end{array}$ & $\begin{array}{l}\text { E (Zhang et al., 2002; Etminan } \\
\text { et al., 2005)* }\end{array}$ & $\begin{array}{l}\text { Protection from PD with } \\
\text { moderate vitamin } E \text { intake }\end{array}$ \\
\hline & $\begin{array}{l}\text { A (Lan and Jiang, 1997; } \\
\text { Roghani and Behzadi, } \\
\text { 2001) }\end{array}$ & $\begin{array}{l}\text { Vitamin E supplementation } \\
\text { protected DA neurons in the SNpc } \\
\text { and reduced DA loss }\end{array}$ & $\begin{array}{l}\text { H (Fernandez-Calle et al., 1992; } \\
\text { LeWitt, 1994; Morens et al., } \\
\text { 1996) }\end{array}$ & $\begin{array}{l}\text { Clinical trials also show no } \\
\text { neuroprotective benefit of } \\
\text { taking vitamin } \mathrm{E}\end{array}$ \\
\hline & $\begin{array}{l}\text { A (Gong et al., 1991; Chi } \\
\text { et al., 1992) }\end{array}$ & $\begin{array}{l}\text { Striatal DA was not attenuated by } \\
\text { pretreatment of vitamin } E\end{array}$ & & \\
\hline & C (Offen et al., 1996) & $\begin{array}{l}\text { Vitamin } E \text { has no protective effects } \\
\text { against DA-induced toxicity in } \\
\text { PC12 cells }\end{array}$ & & \\
\hline & A (Perry et al., 1987) & $\begin{array}{l}\text { Vitamin E partially protected DA } \\
\text { neurons in MPTP rodents }\end{array}$ & & \\
\hline
\end{tabular}


Table 1 | Continued

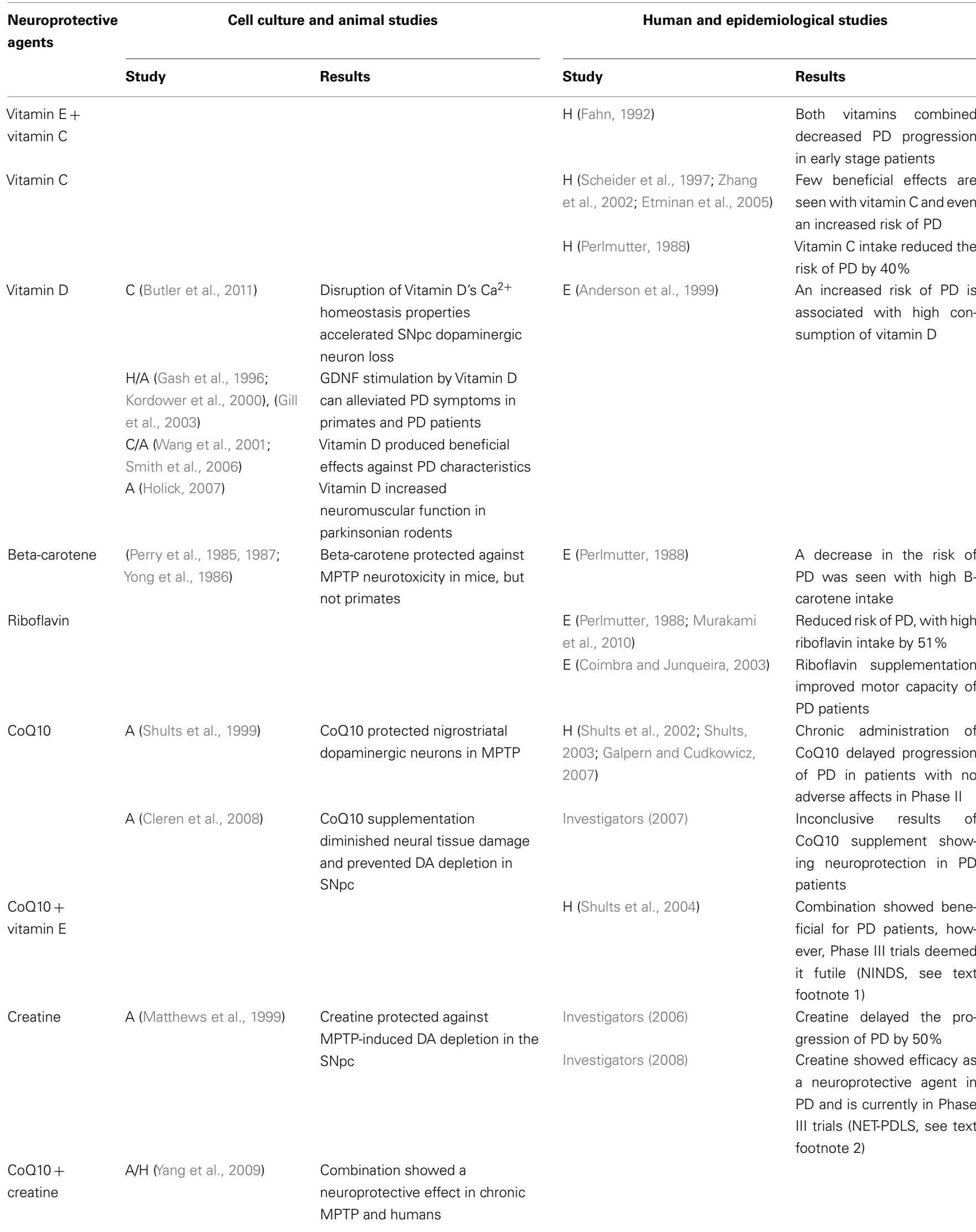


Table 1 | Continued

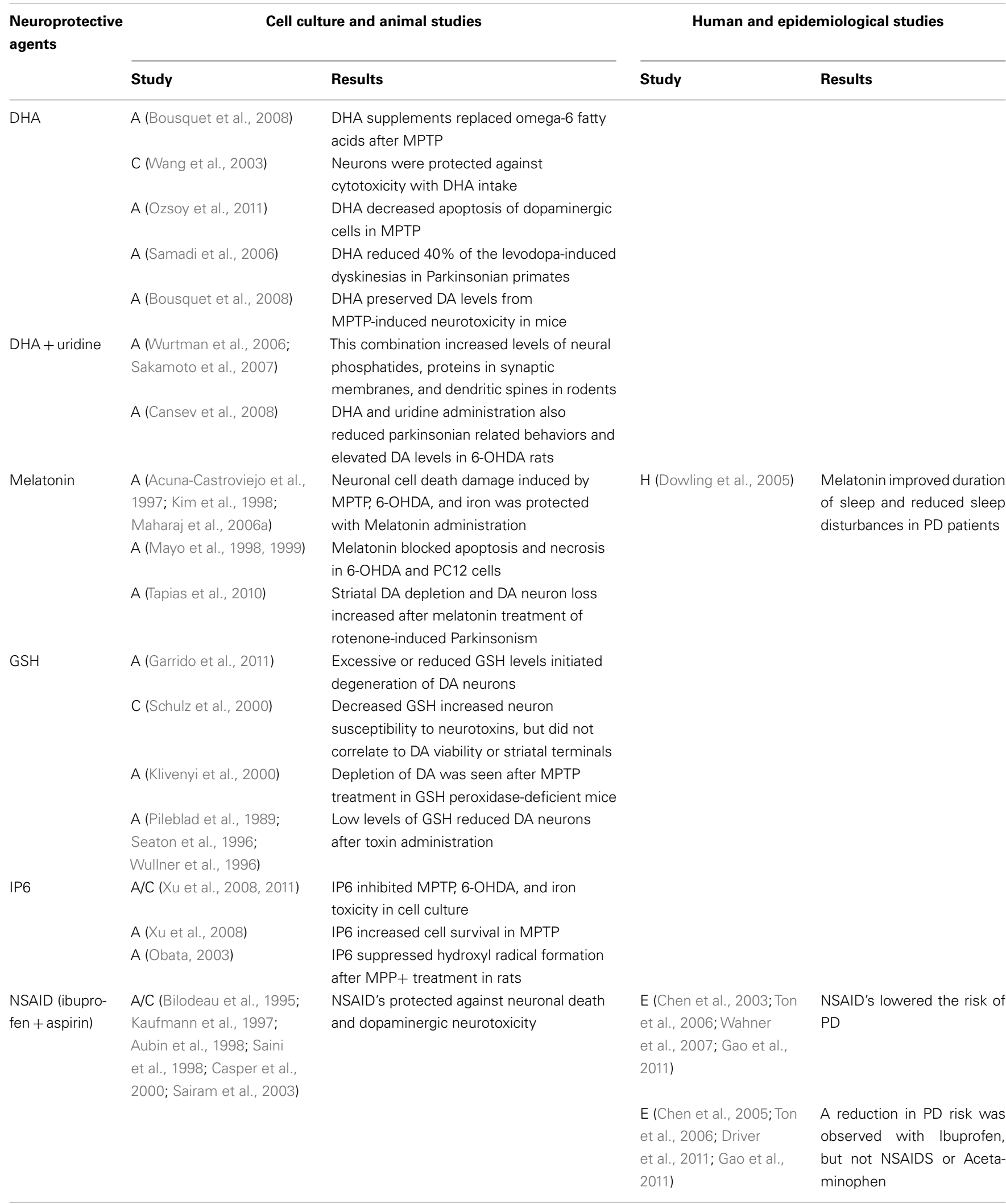


Table 1 | Continued

\begin{tabular}{|c|c|c|c|c|}
\hline \multirow{2}{*}{$\begin{array}{l}\text { Neuroprotective } \\
\text { agents }\end{array}$} & \multicolumn{2}{|c|}{ Cell culture and animal studies } & \multicolumn{2}{|c|}{ Human and epidemiological studies } \\
\hline & Study & Results & Study & Results \\
\hline & A/C (Esposito et al., 2007) & $\begin{array}{l}\text { NSAIDS showed neuroprotection } \\
\text { in MPTP, 6-OHDA, and in vitro }\end{array}$ & E (Becker et al., 2011) & $\begin{array}{l}\text { NSAID's and aspirin showed } \\
\text { no association with altering } \\
\text { the risk of PD }\end{array}$ \\
\hline Isradipine & A (llijic et al., 2011) & $\begin{array}{l}\text { Isradipine showed } \\
\text { neuroprotection against 6-OHDA }\end{array}$ & H (Simuni et al., 2010) & $\begin{array}{l}\text { Isradipine was deemed futile } \\
\text { for human trials }\end{array}$ \\
\hline Ex-4 & A (Li et al., 2009) & $\begin{array}{l}\text { Protected DA neuron } \\
\text { degeneration, preserved DA } \\
\text { levels, and improved motor } \\
\text { function in rodents }\end{array}$ & & \\
\hline & $\begin{array}{l}\text { A/C (Harkavyi et al., 2008; } \\
\text { Li et al., 2009) }\end{array}$ & $\begin{array}{l}\text { Ex-4 protected ventral } \\
\text { mesencephalic dopaminergic cells } \\
\text { in culture, reverse nigral lesions, } \\
\text { and protected against 6-OHDA } \\
\text { toxicity }\end{array}$ & & \\
\hline \multirow[t]{3}{*}{ Rasagiline } & $\begin{array}{l}\text { C:, (Heikkila et al., 1985; } \\
\text { Huang et al., 1999; Speiser } \\
\text { et al., 1999; Maruyama } \\
\text { et al., 2000; Sagi et al., } \\
\text { 2001; Youdim et al., 2001a) }\end{array}$ & $\begin{array}{l}\text { Reduces MPTP and 6-OHDA } \\
\text { toxicity in PC12 and SH-SY5Y cells }\end{array}$ & $\begin{array}{l}\text { H (Hauser et al., 2009; Olanow } \\
\text { et al., 2009) }\end{array}$ & $\begin{array}{l}\text { Rasagiline reduced the long- } \\
\text { term progression and symp- } \\
\text { toms in PD }\end{array}$ \\
\hline & A (Blandini et al., 2004) & $\begin{array}{l}\text { Rasagiline increased DA neuron } \\
\text { survival in lesioned SNpc and } \\
\text { improved motor impairments }\end{array}$ & H (Rascol et al., 2011) & $\begin{array}{l}\text { Rasagiline in a Phase } \\
\text { III delayed the need for } \\
\text { antiparkinsonian drugs and } \\
\text { patients had lower scores } \\
\text { on the Parkinson's disease } \\
\text { rating scale }\end{array}$ \\
\hline & C (Murer et al., 2001) & $\begin{array}{l}\text { Rasagiline increased expression of } \\
\text { neurotrophins }\end{array}$ & & \\
\hline Minocycline & A/C (Du et al., 2001). & $\begin{array}{l}\text { Minocycline blocked } \\
\text { MPTP-induced degeneration of DA } \\
\text { neurons in the SNpc } \sim \text { preventing } \\
\text { loss of striatal DA and its } \\
\text { metabolites. Minocycline } \\
\text { treatment also inhibited MPP+ } \\
\text { mediated inducible NO synthase } \\
\text { expression in vivo and blocked } \\
\text { NO-induced neurotoxicity in vitro }\end{array}$ & H (Investigators, 2006) & $\begin{array}{l}\text { Minocycline was deemed } \\
\text { effective in Phase II slow- } \\
\text { ing the progression of PD in } \\
\text { patients. An 18-month follow } \\
\text { up study showed no safety } \\
\text { concerns with its use (Inves- } \\
\text { tigators, 2008), leading to } \\
\text { Phase III trials }\end{array}$ \\
\hline
\end{tabular}


Table 1 | Continued

\begin{tabular}{|c|c|c|c|c|}
\hline \multirow{2}{*}{$\begin{array}{l}\text { Neuroprotective } \\
\text { agents }\end{array}$} & \multicolumn{2}{|c|}{ Cell culture and animal studies } & \multicolumn{2}{|c|}{ Human and epidemiological studies } \\
\hline & Study & Results & Study & Results \\
\hline & A (Faust et al., 2009; & DA neuroprotection by & & \\
\hline & Radad et al., 2010) & Minocycline was seen in a & & \\
\hline & & $\begin{array}{l}\text { Drosophila model of PD and after } \\
\text { rotenone toxicity in rodents }\end{array}$ & & \\
\hline & A (Quintero et al., 2006). & Reduced the number of & & \\
\hline & & apomorphine-induced rotations in & & \\
\hline & & 6-OHDA-lesioned rats & & \\
\hline \multirow{8}{*}{$\begin{array}{l}\text { A/C (Yang } \\
\text { et al., 2003) }\end{array}$} & & Minocycline exacerbated MPTP & & \\
\hline & & damage to DA neurons in vitro and & & \\
\hline & & in vivo & & \\
\hline & A (Diguet et al., 2004) & Minocycline treatment in primates & & \\
\hline & & and mice produced more & & \\
\hline & & severe/rapid parkinsonism, & & \\
\hline & & behavior deficits, and greater loss & & \\
\hline & & of nerve endings & & \\
\hline $\begin{array}{l}\text { Minocycline }+ \\
\text { creatine }\end{array}$ & & & H (NET-PD, 2006) & $\begin{array}{l}\text { Reduced progression in PD } \\
\text { patients in Phase II }\end{array}$ \\
\hline
\end{tabular}

C, cell culture; A, animal; H, human; and E, epidemiological. Studies showing gender specificity, where males show favorable results are denoted $\left.{ }^{*}\right)$.

(PARP-1) activation, translocation of glyceraldehyde-3-phosphate dehydrogenase (GAPDH), the opening of the MPT and DNA fragmentation (Figure 1; Youdim and Weinstock, 2001; Youdim et al., 2001b, 2003; Akao et al., 2002a; Bar Am et al., 2004; Bar-Am et al., 2004; Weinreb et al., 2004). Rasagiline also increases the expression of the anti-apoptotic proteins Bcl-2 and B-cell lymphomaextra large (Bcl-XL) through the PKC pathway, in addition to down-regulating the pro-apoptotic $\mathrm{Bcl}-2$-associated death promoter (Bad) and Bcl-2-associated X protein (BAX) (Youdim et al., 2001a, 2003; Akao et al., 2002b; Yogev-Falach et al., 2003; Bar Am et al., 2004; Bar-Am et al., 2004; Weinreb et al., 2004).

Minocycline is a semi-synthetic second-generation tetracycline that exerts anti-inflammatory and antioxidant effects (Ryan and Ashley, 1998; Ryan et al., 1998; Faust et al., 2009). Minocycline works by inhibiting the activation of microglia and attenuating the p38 MAPK cascade which reduces inflammatory cytokine synthesis (Figure 1; Yrjanheikki et al., 1998; Tikka et al., 2001; Wu et al., 2002). It is thought that Minocycline's neuroprotective properties may result from inhibition of NO-mediated neurotoxicity (Du et al., 2001). Additionally, Minocycline may be able to chelate metal ions.

In rodents, Minocycline blocked MPTP-induced degeneration of DA neurons in the SNpc, preventing loss of striatal DA, and its metabolites (Du et al., 2001). Minocycline treatment also inhibited $\mathrm{MPP}+$ mediated inducible NO synthase expression in vivo and potently blocked NO-induced neurotoxicity in vitro (Du et al., 2001). Potent DA neuroprotection by Minocycline was also observed in a Drosophila model of PD (Faust et al., 2009) and after chronic rotenone toxicity in rodents (Radad et al., 2010). In addition, Minocycline administration reduced the number of apomorphine-induced rotations in 6-OHDA-lesioned rats, reduced $\mathrm{TH}$-positive cell loss and increased the size and fiber density of the remaining nigral cells (Quintero et al., 2006).

Although Minocycline inhibits microglial activation (Wu et al., 2002), other studies have shown it to significantly exacerbate MPTP-induced damage to DA neurons in vitro and in vivo (Yang et al., 2003). Similarly, Minocycline treatment of monkeys and mice produced more severe and rapid parkinsonism, behavior deficits, and greater loss of nerve endings (Diguet et al., 2004). Lack of neuroprotection was shown to be due to the inability of Minocycline to abolish the activation of TNF- $\alpha$ and its receptors, thereby failing to modulate TNF signaling after MPTP administration (Sriram et al., 2006). Minocycline administration in TNF- $\alpha$ knockout MPTP-treated mice increased leakage of the BBB, but these animals did not exhibit a greater loss of neurons (Zhao et al., 2007). In a phase II clinical trial, Minocycline was deemed effective in slowing the progression of PD in patients (Investigators, 2006) and an 18-month follow up study showed no safety concerns, thus paving the way to a phase III trial (Investigators, 2008). Additionally, neuroprotective effects of Minocycline combined with creatine demonstrate additive benefits in reducing $\mathrm{PD}$ progression in patients, and is currently in clinical trials (NET-PD, 2006).

\section{CONCLUDING REMARIKS}

Some neuroprotective agents show promising results for slowing the progression of PD and these are summarized in Table 1. In general, these agents reduce oxidative stress, mitochondrial dysfunction, protein aggregation, inflammation, excitotoxicity, cell death, iron accumulation, or stimulate neurotrophic factors. In an earlier review, caffeine, CoQ10, creatine, Minocycline, and Rasagiline were identified as the top candidates for preventing neurodegenerative diseases (Ravina et al., 2003). However, current 
research suggests that Minocycline, creatine, and Rasagiline are the most promising agents for neuroprotection in PD and all three are now in Phase III trials. In addition, a combination of Minocycline and creatine is in Phase III trials and CoQ10 and creatine is in Phase II. Other promising neuroprotective agents for PD include nicotine, caffeine, Ibuprofen, and DHA since they show strong neuroprotection. More moderate protective effects are observed with melatonin, vitamin D, and UA. In contrast, vitamin E, vitamin C, NSAIDs, aspirin, GSH, and CoQ10 alone show limited and/or inconsistent results for slowing disease progression. Of the remaining agents, IP6, riboflavin, beta-carotene, Liraglutide, Ex-4, Phenylbutyrate, and Isradipine show promising results in reducing the risk of $\mathrm{PD}$, but further studies are needed to determine if they are neuroprotective in humans. Additionally, caffeine and UA may be promising, but only in male PD patients. These sex-specific

\section{REFERENCES}

Abdin, A. A., and Hamouda, H. E. (2008). Mechanism of the neuroprotective role of coenzyme Q10 with or without L-dopa in rotenoneinduced parkinsonism. Neuropharmacology 55, 1340-1346.

Acuna-Castroviejo, D., Coto-Montes, A., Gaia Monti, M., Ortiz, G. G., and Reiter, R. J. (1997). Melatonin is protective against MPTP-induced striatal and hippocampal lesions. Life Sci. 60, PL23-PL29.

Adhihetty, P. J., and Beal, M. F. (2008). Creatine and its potential therapeutic value for targeting cellular energy impairment in neurodegenerative diseases. Neuromolecular Med. 10, 275-290.

Aguiar, L. M., Nobre, H. V. Jr., Macedo, D. S., Oliveira, A. A., Freitas, R. M., Vasconcelos, S. M., Cunha, G. M., Sousa, F. C., and Viana, G. S. (2006). Neuroprotective effects of caffeine in the model of 6-hydroxydopamine lesion in rats. Pharmacol. Biochem. Behav. 84, 415-419.

Akao, Y., Maruyama, W., Shimizu, S., Yi, H., Nakagawa, Y., ShamotoNagai, M., Youdim, M. B., Tsujimoto, Y., and Naoi, M. (2002a). Mitochondrial permeability transition mediates apoptosis induced by $\mathrm{N}$-methyl(R)salsolinol, an endogenous neurotoxin, and is inhibited by $\mathrm{Bcl}-2$ and rasagiline, $\mathrm{N}$-propargyl1(R)-aminoindan. J. Neurochem. 82, 913-923.

Akao, Y., Maruyama, W., Yi, H., Shamoto-Nagai, M., Youdim, M. B., and Naoi, M. (2002b). An anti-Parkinson's disease drug, Npropargyl-1(R)-aminoindan (rasagiline), enhances expression of antiapoptotic bcl-2 in human dopaminergic SH-SY5Y cells. Neurosci. Lett. 326, 105-108.
Akbar, M., Calderon, F., Wen, Z., and Kim, H. Y. (2005). Docosahexaenoic acid: a positive modulator of Akt signaling in neuronal survival. Proc. Natl. Acad. Sci. U.S.A. 102, 10858-10863.

Akbar, M., and Kim, H. Y. (2002). Protective effects of docosahexaenoic acid in staurosporine-induced apoptosis: involvement of phosphatidylinositol-3 kinase pathway. J. Neurochem. 82, 655-665.

Alonso, A., Rodriguez, L. A., Logroscino, G., and Hernan, M. A. (2007). Gout and risk of Parkinson disease: a prospective study. Neurology 69, 1696-1700.

Ames, B. N., Cathcart, R., Schwiers, E., and Hochstein, P. (1981). Uric acid provides an antioxidant defense in humans against oxidant- and radical-caused aging and cancer: a hypothesis. Proc. Natl. Acad. Sci. U.S.A. 78, 6858-6862.

Anderson, C., Checkoway, H., Franklin, G. M., Beresford, S., Smith-Weller, T., and Swanson, P. D. (1999). Dietary factors in Parkinson's disease: the role of food groups and specific foods. Mov. Disord. 14, 21-27.

Andreadou, E., Nikolaou, C., Gournaras, F., Rentzos, M., Boufidou, F., Tsoutsou, A., Zournas, C., Zissimopoulos, V., and Vassilopoulos, D. (2009). Serum uric acid levels in patients with Parkinson's disease: their relationship to treatment and disease duration. Clin. Neurol. Neurosurg. 111, 724-728.

Annanmaki, T., Muuronen, A., and Murros, K. (2007). Low plasma uric acid level in Parkinson's disease. Mov. Disord. 22, 1133-1137.

Antolin, I., Mayo, J. C., Sainz, R. M., del Brio Mde, L., Herrera, F., Martin, V., and Rodriguez, C. (2002). Protective effect of melatonin in a chronic experimental model of Parkinson's disease. Brain Res. 943, 163-173.

effects are a reminder that it is important to assess each PD patient's response to neuroprotective agents clinically since other unidentified variables, such as single nucleotide polymorphisms (SNPs) and hormones, may also affect an individual's response. Further research addressing the mechanism of the sex differences and how SNPs play a role in the response to neuroprotective agents is needed to optimize a therapeutic approach for treating PD.

\section{ACKNOWLEDGMENTS}

The authors thank Jose Santiago and Mich Beales for critical review of the manuscript. This work was supported by the US Army Medical Research and Materiel Command under award number W81XWH-09-0708. Opinions, conclusions, interpretations and recommendations are those of the author and are not necessarily endorsed by the U.S. Army.

Arvanitakis, Z., Wilson, R. S., Bienias, J. L., Evans, D. A., and Bennett, D. A. (2004). Diabetes mellitus and risk of Alzheimer disease and decline in cognitive function. Arch. Neurol. 61, 661-666.

Ascherio, A., Chen, H., Schwarzschild, M. A., Zhang, S. M., Colditz, G. A., and Speizer, F. E. (2003). Caffeine, postmenopausal estrogen, and risk of Parkinson's disease. Neurology 60, 790-795.

Ascherio, A., LeWitt, P. A., Xu, K., Eberly, S., Watts, A., Matson, W. R., Marras, C., Kieburtz, K., Rudolph, A., Bogdanov, M. B., Schwid, S. R., Tennis, M., Tanner, C. M., Beal, M. F., Lang, A. E., Oakes, D., Fahn, S., Shoulson, I., and Schwarzschild, M. A. (2009). Urate as a predictor of the rate of clinical decline in Parkinson disease. Arch. Neurol. 66, 1460-1468.

Ascherio, A., Zhang, S. M., Hernan, M. A., Kawachi, I., Colditz, G. A., Speizer, F. E., and Willett, W. C. (2001). Prospective study of caffeine consumption and risk of Parkinson's disease in men and women. Ann. Neurol. 50, 56-63.

Aubin, N., Curet, O., Deffois, A., and Carter, C. (1998). Aspirin and salicylate protect against MPTP-induced dopamine depletion in mice. J. Neurochem. 71, 1635-1642.

Bar Am, O., Amit, T., and Youdim, M. B. (2004). Contrasting neuroprotective and neurotoxic actions of respective metabolites of anti-Parkinson drugs rasagiline and selegiline. Neurosci. Lett. 355, 169-172.

Bar-Am, O., Yogev-Falach, M., Amit, T., Sagi, Y., and Youdim, M. B. (2004). Regulation of protein kinase $\mathrm{C}$ by the anti-Parkinson drug, MAO-B inhibitor, rasagiline and its derivatives, in vivo. J. Neurochem. 89, 1119-1125.

Barhwal, K., Hota, S. K., Baitharu, I., Prasad, D., Singh, S. B., and
Ilavazhagan, G. (2009). Isradipine antagonizes hypobaric hypoxia induced CA1 damage and memory impairment: complementary roles of L-type calcium channel and NMDA receptors. Neurobiol. Dis. 34, 230-244.

Bazan, N. G. (2005). Neuroprotectin D1 (NPD1): a DHA-derived mediator that protects brain and retina against cell injury-induced oxidative stress. Brain Pathol. 15, 159-166.

Beal, M. F., and Shults, C. W. (2003). Effects of coenzyme Q10 in Huntington's disease and early Parkinson's disease. Biofactors 18, 153-161.

Becker, C., Jick, S. S., and Meier, C. R. (2011). NSAID use and risk of Parkinson disease: a populationbased case-control study. Eur. J. Neurol. 18, 1336-1342.

Bertilsson, G., Patrone, C., Zachrisson, O., Andersson, A., Dannaeus, K., Heidrich, J., Kortesmaa, J., Mercer, A., Nielsen, E., Ronnholm, H. and Wikstrom, L. (2008). Peptide hormone exendin-4 stimulates subventricular zone neurogenesis in the adult rodent brain and induces recovery in an animal model of Parkinson's disease. J. Neurosci. Res. 86, 326-338.

Bharath, S., Hsu, M., Kaur, D., Rajagopalan, S., and Andersen, J. K. (2002). Glutathione, iron and Parkinson's disease. Biochem. Pharmacol. 64, 1037-1048.

Bilodeau, J. F., Wang, M., Chung, F. L., and Castonguay, A. (1995). Effects of nonsteroidal antiinflammatory drugs on oxidative pathways in A/J mice. Free Radic. Biol. Med. 18, 47-54.

Blandini, F., Armentero, M. T., Fancellu, R., Blaugrund, E., and Nappi, G. (2004). Neuroprotective effect of rasagiline in a rodent model of Parkinson's disease. Exp. Neurol. 187, 455-459. 
Bonifati, V., Rizzu, P., Squitieri, F., Krieger, E., Vanacore, N., van Swieten, J. C., Brice, A., van Duijn, C. M., Oostra, B., Meco, G., and Heutink, P. (2003). DJ-1(PARK7), a novel gene for autosomal recessive, early onset parkinsonism. Neurol. Sci. 24, 159-160.

Bousquet, M., Calon, F., and Cicchetti, F. (2011). Impact of omega-3 fatty acids in Parkinson's disease. Ageing Res. Rev. 10, 453-463.

Bousquet, M., Saint-Pierre, M., Julien, C., Salem, N. Jr., Cicchetti, F., and Calon, F. (2008). Beneficial effects of dietary omega- 3 polyunsaturated fatty acid on toxin-induced neuronal degeneration in an animal model of Parkinson's disease. FASEB J. 22, 1213-1225.

Bove, J., Prou, D., Perier, C., and Przedborski, S. (2005a). Toxin-induced models of Parkinson's disease. NeuroRx 2, 484-494.

Bove, J., Serrats, J., Mengod, G., Cortes, R., Tolosa, E., and Marin, C. (2005b). Neuroprotection induced by the adenosine A2A antagonist CSC in the 6-OHDA rat model of parkinsonism: effect on the activity of striatal output pathways. Exp. Brain Res. 165, 362-374.

Bower, J. H., Maraganore, D. M., Peterson, B. J., Ahlskog, J. E., and Rocca, W. A. (2006). Immunologic diseases, anti-inflammatory drugs, and Parkinson disease: a case-control study. Neurology 67, 494-496.

Burton, G. W., Joyce, A., and Ingold, K. U. (1983). Is vitamin $\mathrm{E}$ the only lipid-soluble, chain-breaking antioxidant in human blood plasma and erythrocyte membranes? Arch. Biochem. Biophys. 221, 281-290.

Butler, M. W., Burt, A., Edwards, T. L., Zuchner, S., Scott, W. K., Martin, E. R., Vance, J. M., and Wang, L. (2011). Vitamin D receptor gene as a candidate gene for Parkinson disease. Ann. Hum. Genet. 75, 201-210.

Calon, F., Lim, G. P., Morihara, T., Yang, F., Ubeda, O., Salem, N. Jr., Frautschy, S. A., and Cole, G. M. (2005). Dietary n-3 polyunsaturated fatty acid depletion activates caspases and decreases NMDA receptors in the brain of a transgenic mouse model of Alzheimer's disease. Eur. J. Neurosci. 22, 617-626.

Calon, F., Lim, G. P., Yang, F., Morihara, T., Teter, B., Ubeda, O., Rostaing, P., Triller, A., Salem, N. Jr., Ashe, K. H., Frautschy, S. A., and Cole, G. M. (2004). Docosahexaenoic acid protects from dendritic pathology in an Alzheimer's disease mouse model. Neuron 43, 633-645.
Cansev, M., Ulus, I. H., Wang, L., Maher, T. J., and Wurtman, R. J. (2008) Restorative effects of uridine plus docosahexaenoic acid in a rat model of Parkinson's disease. Neurosci. Res. 62, 206-209.

Carr, L. A., and Rowell, P. P. (1990). Attenuation of 1-methyl-4-phenyl1,2,3,6-tetrahydropyridine-induced neurotoxicity by tobacco smoke. Neuropharmacology 29, 311-314.

Carrasco, E., Casper, D., and Werner, P. (2005). Dopaminergic neurotoxicity by 6-OHDA and MPP+: differential requirement for neuronal cyclooxygenase activity. J. Neurosci. Res. 81, 121-131.

Casper, D., Yaparpalvi, U., Rempel, N., and Werner, P. (2000). Ibuprofen protects dopaminergic neurons against glutamate toxicity in vitro. Neurosci. Lett. 289, 201-204.

Chan, C. S., Gertler, T. S., and Surmeier, D. J. (2009). Calcium homeostasis, selective vulnerability and Parkinson's disease. Trends Neurosci. 32, 249-256.

Chan, C. S., Guzman, J. N., Ilijic, E., Mercer, J. N., Rick, C., Tkatch, T., Meredith, G. E., and Surmeier, D. J. (2007). 'Rejuvenation' protects neurons in mouse models of Parkinson's disease. Nature 447, 1081-1086.

Cheeseman, K. H., Emery, S., Maddix, S. P., Slater, T. F., Burton, G. W., and Ingold, K. U. (1988). Studies on lipid peroxidation in normal and tumour tissues. The Yoshida rat liver tumour. Biochem. J. 250, 247-252.

Chen, H., Jacobs, E., Schwarzschild, M. A., McCullough, M. L., Calle, E. E., Thun, M. J., and Ascherio, A. (2005). Nonsteroidal antiinflammatory drug use and the risk for Parkinson's disease. Ann. Neurol. 58, 963-967.

Chen, H., Mosley, T. H., Alonso, A., and Huang, X. (2009). Plasma urate and Parkinson's disease in the atherosclerosis risk in communities (ARIC) study. Am. J. Epidemiol. 169, 1064-1069.

Chen, H., Zhang, S. M., Hernan, M. A., Schwarzschild, M. A., Willett, W. C., Colditz, G. A., Speizer, F. E., and Ascherio, A. (2003). Nonsteroidal anti-inflammatory drugs and the risk of Parkinson disease. Arch. Neurol. 60, 1059-1064.

Chen, J. F., Xu, K., Petzer, J. P., Staal, R., Xu, Y. H., Beilstein, M., Sonsalla, P. K., Castagnoli, K., Castagnoli, N. Jr., and Schwarzschild, M. A. (2001). Neuroprotection by caffeine and $\mathrm{A}(2 \mathrm{~A})$ adenosine receptor inactivation in a model of Parkinson's disease. J. Neurosci. 21, RC143.
Chi, D. S., Gong, L., Daigneault, E. A. and Kostrzewa, R. M. (1992). Effects of MPTP and vitamin E treatments on immune function in mice. Int. J. Immunopharmacol. 14, 739-746.

Chinta, S. J., and Andersen, J. K. (2006) Reversible inhibition of mitochondrial complex I activity following chronic dopaminergic glutathione depletion in vitro: implications for Parkinson's disease. Free Radic. Biol. Med. 41, 1442-1448.

Chinta, S. J., Kumar, M. J., Hsu, M. Rajagopalan, S., Kaur, D., Rane, A., Nicholls, D. G., Choi, J., and Andersen, J. K. (2007). Inducible alterations of glutathione levels in adult dopaminergic midbrain neurons result in nigrostriatal degeneration. J. Neurosci. 27, 13997-14006.

Choi, H. K., Atkinson, K., Karlson, E. W. Willett, W., and Curhan, G. (2004). Alcohol intake and risk of incident gout in men: a prospective study. Lancet 363, 1277-1281.

Choi, H. K., Liu, S., and Curhan, G. (2005). Intake of purine-rich foods, protein, and dairy products and relationship to serum levels of uric acid: the Third National Health and Nutrition Examination Survey. Arthritis Rheum. 52, 283-289.

Chow, C. K. (1991). Vitamin E and oxidative stress. Free Radic. Biol. Med. 11, 215-232.

Church, W. H., and Ward, V. L. (1994). Uric acid is reduced in the substantia nigra in Parkinson's disease: effect on dopamine oxidation. Brain Res. Bull. 33, 419-425.

Cleren, C., Yang, L., Lorenzo, B., Calingasan, N. Y., Schomer, A., Sireci, A., Wille, E. J., and Beal, M. F. (2008). Therapeutic effects of coenzyme Q10 (CoQ10) and reduced CoQ10 in the MPTP model of Parkinsonism. J. Neurochem. 104, 1613-1621.

Coimbra, C. G., and Junqueira, V. B. (2003). High doses of riboflavin and the elimination of dietary red meat promote the recovery of some motor functions in Parkinson's disease patients. Braz. J. Med. Biol. Res. 36, 1409-1417.

Costa, G., Abin-Carriquiry, J. A., and Dajas, F. (2001). Nicotine prevents striatal dopamine loss produced by 6-hydroxydopamine lesion in the substantia nigra. Brain Res. 888, 336-342.

Costa, J., Lunet, N., Santos, C., Santos, J., and Vaz-Carneiro, A. (2010). Caffeine exposure and the risk of Parkinson's disease: a systematic review and meta-analysis of observational studies. J. Alzheimers Dis. 20(Suppl. 1), S221-S238. da Silva, T. M., Munhoz, R. P., Alvarez, C., Naliwaiko, K., Kiss, A., Andreatini, R., and Ferraz, A. C. (2008). Depression in Parkinson's disease: a double-blind, randomized, placebocontrolled pilot study of omega-3 fatty-acid supplementation. J. Affect. Disord. 111, 351-359.

Davies, K. J., Sevanian, A., MuakkassahKelly, S. F., and Hochstein, P. (1986). Uric acid-iron ion complexes. A new aspect of the antioxidant functions of uric acid. Biochem. J. 235, 747-754.

de Lau, L. M., Koudstaal, P. J., Hofman, A., and Breteler, M. M. (2005). Serum uric acid levels and the risk of Parkinson disease. Ann. Neurol. 58, 797-800.

de Urquiza, A. M., Liu, S., Sjoberg, M. Zetterstrom, R. H., Griffiths, W., Sjovall, J., and Perlmann, T. (2000). Docosahexaenoic acid, a ligand for the retinoid $\mathrm{X}$ receptor in mouse brain. Science 290, 2140-2144.

Dedeoglu, A., Kubilus, J. K., Yang, L., Ferrante, K. L., Hersch, S. M., Beal, M. F., and Ferrante, R. J. (2003). Creatine therapy provides neuroprotection after onset of clinical symptoms in Huntington's disease transgenic mice. J. Neurochem. 85 , 1359-1367.

Dexter, D. T., Ward, R. J., Wells, F. R., Daniel, S. E., Lees, A. J., Peters, T. J., Jenner, P., and Marsden, C. D. (1992). Alpha-tocopherol levels in brain are not altered in Parkinson's disease. Ann. Neurol. 32, 591-593.

Di Matteo, V., Pierucci, M., Di Giovanni, G., Di Santo, A., Poggi, A., Benigno, A., and Esposito, E. (2006). Aspirin protects striatal dopaminergic neurons from neurotoxininduced degeneration: an in vivo microdialysis study. Brain Res. 1095, 167-177.

Di Monte, D. A. (1991). Mitochondrial DNA and Parkinson's disease. Neurology 41, 38-42; discussion 42-33.

Diguet, E., Fernagut, P. O., Wei, X., Du, Y., Rouland, R., Gross, C., Bezard, E., and Tison, F. (2004). Deleterious effects of minocycline in animal models of Parkinson's disease and Huntington's disease. Eur. J. Neurosci. 19, 3266-3276.

Dowling, G. A., Mastick, J., Colling, E., Carter, J. H., Singer, C. M., and Aminoff, M. J. (2005). Melatonin for sleep disturbances in Parkinson's disease. Sleep Med. 6, 459-466.

Driver, J. A., Logroscino, G., Lu, L., Gaziano, J. M., and Kurth, T. (2011). Use of non-steroidal antiinflammatory drugs and risk of Parkinson's disease: nested casecontrol study. BMJ 342, d198. 
Du, Y., Ma, Z., Lin, S., Dodel, R. C., Gao, F., Bales, K. R., Triarhou, L. C., Chernet, E., Perry, K. W., Nelson, D. L., Luecke, S., Phebus, L. A., Bymaster, F. P., and Paul, S. M. (2001). Minocycline prevents nigrostriatal dopaminergic neurodegeneration in the MPTP model of Parkinson's disease. Proc. Natl. Acad. Sci. U.S.A. 98, 14669-14674.

Duan, W., Ladenheim, B., Cutler, R. G., Kruman, II, Cadet, J. L., and Mattson, M. P. (2002). Dietary folate deficiency and elevated homocysteine levels endanger dopaminergic neurons in models of Parkinson's disease. J. Neurochem. 80, 101-110.

During, M. J., Cao, L., Zuzga, D. S., Francis, J. S., Fitzsimons, H. L., Jiao, X., Bland, R. J., Klugmann, M., Banks, W. A., Drucker, D. J., and Haile, C. N. (2003). Glucagon-like peptide1 receptor is involved in learning and neuroprotection. Nat. Med. 9, 1173-1179.

Ebadi, M., Sharma, S. K., Wanpen, S., and Amornpan, A. (2004). Coenzyme Q10 inhibits mitochondrial complex-1 down-regulation and nuclear factor-kappa B activation. $J$. Cell. Mol. Med. 8, 213-222.

Esposito, E., Di Matteo, V., Benigno, A., Pierucci, M., Crescimanno, G., and Di Giovanni, G. (2007). Nonsteroidal anti-inflammatory drugs in Parkinson's disease. Exp. Neurol.205, 295-312.

Etminan, M., Gill, S. S., and Samii, A. (2005). Intake of vitamin E, vitamin $\mathrm{C}$, and carotenoids and the risk of Parkinson's disease: a meta-analysis. Lancet Neurol. 4, 362-365.

Evans, R. M. (1988). The steroid and thyroid hormone receptor superfamily. Science 240, 889-895.

Everse, J., and Coates, P. W. (2004). The cytotoxic activity of lactoperoxidase: enhancement and inhibition by neuroactive compounds. Free Radic. Biol. Med. 37, 839-849.

Eyles, D., Brown, J., Mackay-Sim, A., McGrath, J., and Feron, F. (2003). Vitamin D3 and brain development. Neuroscience 118, 641-653.

Eyles, D. W., Smith, S., Kinobe, R., Hewison, M., and McGrath, J. J. (2005). Distribution of the vitamin $D$ receptor and 1 alpha-hydroxylase in human brain. J. Chem. Neuroanat. 29, 21-30.

Fahn, S. (1992). A pilot trial of highdose alpha-tocopherol and ascorbate in early Parkinson's disease. Ann. Neurol. 32(Suppl.), S128-S132.

Fariss, M. W., and Zhang, J. G. (2003). Vitamin E therapy in Parkinson's disease. Toxicology 189, 129-146.

Faust, K., Gehrke, S., Yang, Y., Yang, L., Beal, M. F., and Lu, B. (2009). Neuroprotective effects of compounds with antioxidant and anti-inflammatory properties in a Drosophila model of Parkinson's disease. BMC Neurosci. 10, 109. doi:10.1186/1471-2202-10-109

Ferger, B., Spratt, C., Earl, C. D., Teismann, P., Oertel, W. H., and Kuschinsky, K. (1998). Effects of nicotine on hydroxyl free radical formation in vitro and on MPTP-induced neurotoxicity in vivo. Naunyn Schmiedebergs Arch. Pharmacol. 358, 351-359.

Fernandez-Calle, P., Jimenez-Jimenez, F. J., Molina, J. A., Cabrera-Valdivia, F., Vazquez, A., Garcia Urra, D., Bermejo, F., Cruz Matallana, M., and Codoceo, R. (1993). Serum levels of ascorbic acid (vitamin C) in patients with Parkinson's disease. J. Neurol. Sci. 118, 25-28.

Fernandez-Calle, P., Molina, J. A., Jimenez-Jimenez, F. J., Vazquez, A., Pondal, M., Garcia-Ruiz, P. J., Urra, D. G., Domingo, J., and Codoceo, R. (1992). Serum levels of alpha-tocopherol (vitamin E) in Parkinson's disease. Neurology 42, 1064-1066.

Ferrea, S., and Winterer, G. (2009). Neuroprotective and neurotoxic effects of nicotine. Pharmacopsychiatry 42, 255-265.

Fertl, E., Auff, E., Doppelbauer, A., and Waldhauser, F. (1993). Circadian secretion pattern of melatonin in de novo parkinsonian patients: evidence for phase-shifting properties of l-dopa. J. Neural Transm. Park. Dis. Dement. Sect. 5, 227-234.

Fowler, J. S., Volkow, N. D., Wang, G. J., Pappas, N., Logan, J., MacGregor, R., Alexoff, D., Shea, C., Schlyer, D., Wolf, A. P., Warner, D., Zezulkova, I., and Cilento, R. (1996). Inhibition of monoamine oxidase $\mathrm{B}$ in the brains of smokers. Nature 379, 733-736.

Galpern, W. R., and Cudkowicz, M. E. (2007). Coenzyme Q treatment of neurodegenerative diseases of aging. Mitochondrion 7(Suppl.), S146-S153.

Gao, X., Chen, H., Choi, H. K., Curhan, G., Schwarzschild, M. A., and Ascherio, A. (2008). Diet, urate, and Parkinson's disease risk in men. Am. J. Epidemiol. 167, 831-838.

Gao, X., Chen, H., Schwarzschild, M. A., and Ascherio, A. (2011). Use of ibuprofen and risk of Parkinson disease. Neurology 76, 863-869.

Garcion, E., Wion-Barbot, N., MonteroMenei, C. N., Berger, F., and Wion, D. (2002). New clues about vitamin D functions in the nervous system. Trends Endocrinol. Metab. 13, 100-105.

Gardian, G., Yang, L., Cleren, C., Calingasan, N. Y., Klivenyi, P., and Beal, M. F. (2004). Neuroprotective effects of phenylbutyrate against MPTP neurotoxicity. Neuromolecular Med. 5, 235-241.

Garrido, M., Tereshchenko, Y. Zhevtsova, Z., Taschenberger, G., Bahr, M., and Kugler, S. (2011). Glutathione depletion and overproduction both initiate degeneration of nigral dopaminergic neurons. Acta Neuropathol. 121, 475-485.

Gash, D. M., Zhang, Z., Ovadia, A., Cass, W. A., Yi, A., Simmerman, L., Russell, D., Martin, D., Lapchak, P. A., Collins, F., Hoffer, B. J., and Gerhardt, G. A. (1996). Functional recovery in parkinsonian monkeys treated with GDNF. Nature 380 , 252-255.

Gill, S. S., Patel, N. K., Hotton, G. R., O'Sullivan, K., McCarter, R., Bunnage, M., Brooks, D. J., Svendsen, C. N., and Heywood, P. (2003). Direct brain infusion of glial cell line-derived neurotrophic factor in Parkinson disease. Nat. Med. 9, 589-595.

Glover, J. (1960). The conversion of beta-carotene into vitamin A. Vitam. Horm. 18, 371-386.

Gong, L., Daigneault, E. A., Acuff, R. V., and Kostrzewa, R. M. (1991). Vitamin E supplements fail to protect mice from acute MPTP neurotoxicity. Neuroreport 2, 544-546.

Gotz, M. E., Gerstner, A., Harth, R., Dirr, A., Janetzky, B., Kuhn, W., Riederer, P., and Gerlach, M. (2000). Altered redox state of platelet coenzyme Q10 in Parkinson's disease. J. Neural Transm. 107, 41-48.

Green, K. N., Martinez-Coria, H. Khashwji, H., Hall, E. B., YurkoMauro, K. A., Ellis, L., and LaFerla, F M. (2007). Dietary docosahexaenoic acid and docosapentaenoic acid ameliorate amyloid-beta and tau pathology via a mechanism involving presenilin 1 levels. J. Neurosci. 27, 4385-4395.

Grunewald, R. A. (1993). Ascorbic acid in the brain. Brain Res. Brain Res. Rev. 18, 123-133.

Hargreaves, I. P., Lane, A., and Sleiman, P. M. (2008). The coenzyme Q10 status of the brain regions of Parkinson's disease patients. Neurosci. Lett. 447, 17-19.

Harkavyi, A., Abuirmeileh, A., Lever, R., Kingsbury, A. E., Biggs, C. S., and Whitton, P. S. (2008). Glucagonlike peptide 1 receptor stimulation reverses key deficits in distinct rodent models of Parkinson's disease. J. Neuroinflammation 5, 19.

Harkavyi, A., and Whitton, P. S. (2010). Glucagon-like peptide 1 receptor stimulation as a means of neuroprotection. Br. J. Pharmacol. 159, 495-501.
Hashimoto, M., Hossain, S., Shimada, T., Sugioka, K., Yamasaki, H., Fujii, Y., Ishibashi, Y., Oka, J., and Shido, O. (2002). Docosahexaenoic acid provides protection from impairment of learning ability in Alzheimer's disease model rats. J. Neurochem. 81, 1084-1091.

Hashimoto, M., Tanabe, Y., Fujii, Y., Kikuta, T., Shibata, H., and Shido, O. (2005). Chronic administration of docosahexaenoic acid ameliorates the impairment of spatial cognition learning ability in amyloid beta-infused rats. J. Nutr. 135, 549-555.

Hauser, R. A., Lew, M. F., Hurtig, H. I., Ondo, W. G., Wojcieszek, J., and Fitzer-Attas, C. J. (2009). Long-term outcome of early versus delayed rasagiline treatment in early Parkinson's disease. Mov. Disord. 24, 564-573.

Heales, S. J., Menzes, A., and Davey, G. P. (2011). Depletion of glutathione does not affect electron transport chain complex activity in brain mitochondria: implications for Parkinson disease and postmortem studies. Free Radic. Biol. Med. 50, 899-902.

Heikkila, R. E., Manzino, L., Cabbat, F. S., and Duvoisin, R. C. (1985). Studies on the oxidation of the dopaminergic neurotoxin 1-methyl-4-phenyl-1,2,5,6tetrahydropyridine by monoamine oxidase B. J. Neurochem. 45, 1049-1054.

Hernan, M. A., Logroscino, G., and Garcia Rodriguez, L. A. (2006). Nonsteroidal anti-inflammatory drugs and the incidence of Parkinson disease. Neurology 66, 1097-1099.

Hink, H. U., Santanam, N., Dikalov, S., McCann, L., Nguyen, A. D., Parthasarathy, S., Harrison, D. G., and Fukai, T. (2002). Peroxidase properties of extracellular superoxide dismutase: role of uric acid in modulating in vivo activity. Arterioscler. Thromb. Vasc. Biol. 22, 1402-1408.

Hirsch, E. C., and Hunot, S. (2009). Neuroinflammation in Parkinson's disease: a target for neuroprotection? Lancet Neurol. 8, 382-397.

Holick, M. F. (2007). Vitamin D deficiency. N. Engl. J. Med.357, 266-281.

Holmes, A. D., Copland, D. A., Silburn, P. A., and Chenery, H. J. (2011). Acute nicotine enhances strategy-based semantic processing in Parkinson's disease. Int. J. Neuropsychopharmacol. 14, 877-885.

Holst, J. J., Burcelin, R., and Nathanson, E. (2011). Neuroprotective properties of GLP-1: theoretical and practical applications. Curr. Med. Res. Opin. 27, 547-558. 
Horrocks, L. A., and Yeo, Y. K. (1999). Health benefits of docosahexaenoic acid (DHA). Pharmacol. Res. 40, 211-225.

Huang, W., Chen, Y., Shohami, E., and Weinstock, M. (1999). Neuroprotective effect of rasagiline, a selective monoamine oxidase-B inhibitor, against closed head injury in the mouse. Eur. J. Pharmacol. 366, 127-135.

Huennekens, F. M. (1956). Flavin nucleotides and flavoproteins. Experientia $12,1-6$.

Ibanez, P., De Michele, G., Bonifati, V., Lohmann, E., Thobois, S., Pollak, P., Agid, Y., Heutink, P., Durr, A., and Brice, A. (2003). Screening for DJ-1 mutations in early onset autosomal recessive parkinsonism. Neurology 61, 1429-1431.

Iida, M., Miyazaki, I., Tanaka, K., Kabuto, H., Iwata-Ichikawa, E., and Ogawa, N. (1999). Dopamine D2 receptor-mediated antioxidant and neuroprotective effects of ropinirole, a dopamine agonist. Brain Res. 838 , 51-59.

Ilijic, E., Guzman, J. N., and Surmeier, D. J. (2011). The L-type channel antagonist isradipine is neuroprotective in a mouse model of Parkinson's disease. Neurobiol. Dis. 43, 364-371.

Inden, M., Kitamura, Y., Takeuchi, H., Yanagida, T., Takata, K., Kobayashi, Y., Taniguchi, T., Yoshimoto, K., Kaneko, M., Okuma, Y., Taira, T., Ariga, H., and Shimohama, S. (2007). Neurodegeneration of mouse nigrostriatal dopaminergic system induced by repeated oral administration of rotenone is prevented by 4-phenylbutyrate, a chemical chaperone. J. Neurochem. 101, 1491-1504.

Investigators, N. N.-P. (2006). A randomized, double-blind, futility clinical trial of creatine and minocycline in early Parkinson disease. Neurology 66, 664-671.

Investigators, N. N.-P. (2007). A randomized clinical trial of coenzyme Q10 and GPI-1485 in early Parkinson disease. Neurology 68, 20-28.

Investigators, N. N.-P. (2008). A pilot clinical trial of creatine and minocycline in early Parkinson disease: 18month results. Clin. Neuropharmacol. 31, 141-150.

Jeerakathil, T., Johnson, J. A., Simpson, S. H., and Majumdar, S. R. (2007). Short-term risk for stroke is doubled in persons with newly treated type 2 diabetes compared with persons without diabetes: a populationbased cohort study. Stroke 38, 1739-1743.
Jenner, P. (2003). Oxidative stress in Parkinson's disease. Ann. Neurol. 53(Suppl. 3), S26-S36; discussion S36-S28.

Jenner, P., Schapira, A. H., and Marsden, C. D. (1992). New insights into the cause of Parkinson's disease. Neurology 42, 2241-2250.

Jimenez-Jimenez, F. J., Molina, J. A., Fernandez-Calle, P., Vazquez, A., Cabrera-Valdivia, F., Catalan, M. J., Garcia-Albea, E., Bermejo, F., and Codoceo, R. (1993). Serum levels of beta-carotene and other carotenoids in Parkinson's disease. Neurosci. Lett. 157, 103-106.

Joghataie, M. T., Roghani, M., Negahdar, F., and Hashemi, L. (2004). Protective effect of caffeine against neurodegeneration in a model of Parkinson's disease in rat: behavioral and histochemical evidence. Parkinsonism Relat. Disord. 10, 465-468.

Jones, D. C., Gunasekar, P. G., Borowitz, J. L., and Isom, G. E. (2000). Dopamine-induced apoptosis is mediated by oxidative stress and is enhanced by cyanide in differentiated PC12 cells. J. Neurochem. 74, 2296-2304.

Jump, D. B. (2002). Dietary polyunsaturated fatty acids and regulation of gene transcription. Curr. Opin. Lipidol. 13, 155-164.

Kachroo, A., Irizarry, M. C., and Schwarzschild, M. A. (2010). Caffeine protects against combined paraquat and maneb-induced dopaminergic neuron degeneration. Exp. Neurol. 223, 657-661.

Kaempf-Rotzoll, D. E., Traber, M. G., and Arai, H. (2003). Vitamin E and transfer proteins. Curr. Opin. Lipidol. 14, 249-254.

Kartha, V. N., and Krishnamurthy, S. (1977). Antioxidant function of vitamin A. Int. J. Vitam. Nutr. Res. 47, 394-401.

Kaufmann, W. E., Andreasson, K. I., Isakson, P. C., and Worley, P. F. (1997). Cyclooxygenases and the central nervous system. Prostaglandins 54, 601-624.

Khaldy, H., Escames, G., Leon, J., Vives, F., Luna, J. D., and AcunaCastroviejo, D. (2000). Comparative effects of melatonin, L-deprenyl, Trolox and ascorbate in the suppression of hydroxyl radical formation during dopamine autoxidation in vitro. J. Pineal Res. 29, 100-107.

Kim, H. Y. (2007). Novel metabolism of docosahexaenoic acid in neural cells. J. Biol. Chem. 282, 18661-18665.

Kim, S., Moon, M., and Park, S. (2009). Exendin-4 protects dopaminergic neurons by inhibition of microglial activation and matrix metalloproteinase-3 expression in an animal model of Parkinson's disease. J. Endocrinol. 202, 431-439.

Kim, Y. S., Joo, W. S., Jin, B. K., Cho, Y. H., Baik, H. H., and Park, C. W. (1998). Melatonin protects 6OHDA-induced neuronal death of nigrostriatal dopaminergic system. Neuroreport 9, 2387-2390.

Klivenyi, P., Andreassen, O. A., Ferrante, R. J., Dedeoglu, A., Mueller, G., Lancelot, E., Bogdanov, M. Andersen, J. K., Jiang, D., and Beal, M. F. (2000). Mice deficient in cellular glutathione peroxidase show increased vulnerability to malonate, 3-nitropropionic acid, and 1-methyl-4-phenyl-1,2,5,6tetrahydropyridine. J. Neurosci. 20, 1-7.

Kordower, J. H., Emborg, M. E., Bloch, J., Ma, S. Y., Chu, Y., Leventhal, L., McBride, J., Chen, E. Y., Palfi, S., Roitberg, B. Z., Brown, W. D., Holden, J. E., Pyzalski, R., Taylor, M. D., Carvey, P., Ling, Z., Trono, D., Hantraye, P., Deglon, N., and Aebischer, P. (2000). Neurodegeneration prevented by lentiviral vector delivery of GDNF in primate models of Parkinson's disease. Science 290, 767-773.

Kumar, C., Igbaria, A., D’Autreaux, B., Planson, A. G., Junot, C., Godat, E., Bachhawat, A. K., Delaunay-Moisan, A., and Toledano, M. B. (2011). Glutathione revisited: a vital function in iron metabolism and ancillary role in thiol-redox control. EMBO J. 30, 2044-2056.

Kupsch, A., Gerlach, M., Pupeter, S. C., Sautter, J., Dirr, A., Arnold, G., Opitz, W., Przuntek, H., Riederer, P., and Oertel, W. H. (1995). Pretreatment with nimodipine prevents MPTP-induced neurotoxicity at the nigral, but not at the striatal level in mice. Neuroreport 6, 621-625.

Kupsch, A., Sautter, J., Gotz, M. E., Breithaupt, W., Schwarz, J., Youdim, M. B., Riederer, P., Gerlach, M., and Oertel, W. H. (2001). Monoamine oxidase-inhibition and MPTP-induced neurotoxicity in the non-human primate: comparison of rasagiline (TVP 1012) with selegiline. J. Neural Transm. 108, 985-1009.

Kupsch, A., Sautter, J., Schwarz, J., Riederer, P., Gerlach, M., and Oertel, W. H. (1996). 1-Methyl-4-phenyl1,2,3,6-tetrahydropyridine-induced neurotoxicity in non-human primates is antagonized by pretreatment with nimodipine at the nigral, but not at the striatal level. Brain Res. 741, 185-196.
Lan, J., and Jiang, D. H. (1997). Desferrioxamine and vitamin E protect against iron and MPTP-induced neurodegeneration in mice. J. Neural Transm. 104, 469-481.

Lang, A. E., and Lozano, A. M. (1998). Parkinson's disease. First of two parts. N. Engl. J. Med. 339, 1044-1053.

Langston, J. W. (1998). Epidemiology versus genetics in Parkinson's disease: progress in resolving an age-old debate. Ann. Neurol. 44, S45-S52.

Lawler, J. M., Barnes, W. S., Wu, G., Song, W., and Demaree, S. (2002). Direct antioxidant properties of creatine. Biochem. Biophys. Res. Commun. 290, 47-52.

Lazaroff, M., Patankar, S., Yoon, S. O., and Chikaraishi, D. M. (1995). The cyclic AMP response element directs tyrosine hydroxylase expression in catecholaminergic central and peripheral nervous system cell lines from transgenic mice. J. Biol. Chem. 270, 21579-21589.

LeWitt, P. A. (1994). Clinical trials of neuroprotection in Parkinson's disease: long-term selegiline and alpha-tocopherol treatment. $J$. Neural Transm. Suppl. 43, 171-181.

Li, Y., Liu, L., Barger, S. W., Mrak, R. E., and Griffin, W. S. (2001). Vitamin E suppression of microglial activation is neuroprotective. J. Neurosci. Res. 66, 163-170.

Li, Y., Perry, T., Kindy, M. S., Harvey, B. K., Tweedie, D., Holloway, H. W., Powers, K., Shen, H., Egan, J. M., Sambamurti, K., Brossi, A., Lahiri, D. K., Mattson, M. P., Hoffer, B. J., Wang, Y., and Greig, N. H. (2009). GLP-1 receptor stimulation preserves primary cortical and dopaminergic neurons in cellular and rodent models of stroke and Parkinsonism. Proc. Natl. Acad. Sci. U.S.A. 106, 1285-1290.

Lim, G. P., Calon, F., Morihara, T., Yang, F., Teter, B., Ubeda, O., Salem, N. Jr., Frautschy, S. A., and Cole, G. M. (2005). A diet enriched with the omega-3 fatty acid docosahexaenoic acid reduces amyloid burden in an aged Alzheimer mouse model. J. Neurosci. 25, 3032-3040.

Linville, D. G., Williams, S., Raszkiewicz, J. L., and Arneric, S. P. (1993). Nicotinic agonists modulate basal forebrain control of cortical cerebral blood flow in anesthetized rats. $J$. Pharmacol. Exp. Ther. 267, 440-448. Logroscino, G., Marder, K., Graziano, J. Freyer, G., Slavkovich, V., LoIacono, N., Cote, L., and Mayeux, R. (1997). Altered systemic iron metabolism in Parkinson's disease. Neurology 49, 714-717. 
Maggio, R., Riva, M., Vaglini, F., Fornai, F., Racagni, G., and Corsini, G. U. (1997). Striatal increase of neurotrophic factors as a mechanism of nicotine protection in experimental parkinsonism. J. Neural Transm. 104, 1113-1123.

Maharaj, D. S., Maharaj, H., Daya, S., and Glass, B. D. (2006a). Melatonin and 6-hydroxymelatonin protect against iron-induced neurotoxicity. J. Neurochem. 96, 78-81.

Maharaj, H., Maharaj, D. S., and Daya, S. (2006b). Acetylsalicylic acid and acetaminophen protect against MPP+-induced mitochondrial damage and superoxide anion generation. Life Sci. 78, 2438-2443.

Martin, H. L., and Teismann, P. (2009). Glutathione-a review on its role and significance in Parkinson's disease. FASEB J. 23, 3263-3272.

Martin, V., Sainz, R. M., Antolin, I., Mayo, J. C., Herrera, F., and Rodriguez, C. (2002). Several antioxidant pathways are involved in astrocyte protection by melatonin. J. Pineal Res. 33, 204-212.

Maruyama, W., Akao, Y., Youdim, M. B., and Naoi, M. (2000). Neurotoxins induce apoptosis in dopamine neurons: protection by N-propargylamine-1(R)- and (S)aminoindan, rasagiline and TV1022. J. Neural Transm. Suppl. 60, 171-186.

Massaro, M., Habib, A., Lubrano, L., Del Turco, S., Lazzerini, G., Bourcier, T., Weksler, B. B., and De Caterina, R. (2006). The omega-3 fatty acid docosahexaenoate attenuates endothelial cyclooxygenase- 2 induction through both $\mathrm{NADP}(\mathrm{H})$ oxidase and PKC epsilon inhibition. Proc. Natl. Acad. Sci. U.S.A. 103, 15184-15189.

Matsubara, T., Azums, T., Yoshids, S., and Yamegami, T. (1991). Biomedical and Clinical Aspects of Coenzyme Q, Vol. 16. Amsterdam: Elsevier Science, 159-166.

Matthews, R. T., Ferrante, R. J., Klivenyi, P., Yang, L., Klein, A. M., Mueller, G., Kaddurah-Daouk, R., and Beal, M. F. (1999). Creatine and cyclocreatine attenuate MPTP neurotoxicity. Exp. Neurol. 157, 142-149.

Mayo, J. C., Sainz, R. M., Antolin, I., and Rodriguez, C. (1999). Ultrastructural confirmation of neuronal protection by melatonin against the neurotoxin 6-hydroxydopamine cell damage. Brain Res. 818, 221-227.

Mayo, J. C., Sainz, R. M., Tan, D. X., Antolin, I., Rodriguez, C., and Reiter, R. J. (2005). Melatonin and Parkinson's disease. Endocrine 27, 169-178.
Mayo, J. C., Sainz, R. M., Uria, H., Antolin, I., Esteban, M. M., and Rodriguez, C. (1998). Melatonin prevents apoptosis induced by 6hydroxydopamine in neuronal cells: implications for Parkinson's disease. J. Pineal Res. 24, 179-192.

McClean, P. L., Parthsarathy, V., Faivre, E., and Holscher, C. (2010). The novel GLP-1 analogue liraglutide has neuroprotective properties in a mouse model of Alzheimer's disease. Regul. Pept. 164, 40.

McClean, P. L., Parthsarathy, V., Faivre, E., and Holscher, C. (2011). The diabetes drug liraglutide prevents degenerative processes in a mouse model of Alzheimer's disease. J. Neurosci. 31, 6587-6594.

Merrill, A. H. Jr., Lambeth, J. D., Edmondson, D. E., and McCormick, D. B. (1981). Formation and mode of action of flavoproteins. Annu. Rev. Nutr. 1, 281-317.

Meshul, C. K., Kamel, D., Moore, C., Kay, T. S., and Krentz, L. (2002). Nicotine alters striatal glutamate function and decreases the apomorphineinduced contralateral rotations in 6OHDA-lesioned rats. Exp. Neurol. 175, 257-274.

Michel, P. P., Hirsch, E. C., and Agid, Y. (2002). Parkinson's disease: cell death mechanisms. Rev. Neurol. (Paris) 158, 24-32.

Miller, J. W., Selhub, J., and Joseph, J. A. (1996). Oxidative damage caused by free radicals produced during catecholamine autoxidation: protective effects of O-methylation and melatonin. Free Radic. Biol. Med. 21, 241-249.

Molina, J. A., de Bustos, F., JimenezJimenez, F. J., Benito-Leon, J., OrtiPareja, M., Gasalla, T., TallonBarranco, A., Navarro, J. A., Arenas, J., and Enriquez-de-Salamanca, R. (1997). Cerebrospinal fluid levels of alpha-tocopherol (vitamin E) in Parkinson's disease. J. Neural Transm. 104, 1287-1293.

Morens, D. M., Grandinetti, A., Waslien, C. I., Park, C. B., Ross, G. W., and White, L. R. (1996). Case-control study of idiopathic Parkinson's disease and dietary vitamin $\mathrm{E}$ intake. Neurology 46, 1270-1274.

Morioka, N., Kumagai, K., Morita, K., Kitayama, S., and Dohi, T. (2004). Nonsteroidal antiinflammatory drugs potentiate 1-methyl-4-phenylpyridinium (MPP+)-induced cell death by promoting the intracellular accumulation of MPP+ in PC12 cells. J. Pharmacol. Exp. Ther. 310, 800-807.
Murakami, K., Miyake, Y., Sasaki, S. Tanaka, K., Fukushima, W., Kiyohara, C., Tsuboi, Y., Yamada, T., Oeda, T., Miki, T., Kawamura, N. Sakae, N., Fukuyama, H., Hirota, Y. and Nagai, M. (2010). Dietary intake of folate, vitamin B6, vitamin B12 and riboflavin and risk of Parkinson's disease: a case-control study in Japan. Br. J. Nutr. 104, 757-764.

Murer, M. G., Yan, Q., and RaismanVozari, R. (2001). Brain-derived neurotrophic factor in the control human brain, and in Alzheimer's disease and Parkinson's disease. Prog. Neurobiol. 63, 71-124.

Nakaso, K., Ito, S., and Nakashima, K. (2008). Caffeine activates the PI3K/Akt pathway and prevents apoptotic cell death in a Parkinson's disease model of SH-SY5Y cells. Neurosci. Lett. 432, 146-150.

Naveilhan, P., Neveu, I., Wion, D. and Brachet, P. (1996). 1,25Dihydroxyvitamin D3, an inducer of glial cell line-derived neurotrophic factor. Neuroreport 7, 2171-2175.

NET-PD, N. (2006). A randomized, double-blind, futility clinical trial of creatine and minocycline in early Parkinson disease. Neurology 66, 664-671.

Obata, T. (2003). Phytic acid suppresses 1-methyl-4-phenylpyridinium ioninduced hydroxyl radical generation in rat striatum. Brain Res. 978, 241-244.

Odunze, I. N., Klaidman, L. K., and Adams, J. D. Jr. (1990). MPTP toxicity in the mouse brain and vitamin E. Neurosci. Lett. 108, 346-349.

Offen, D., Ziv, I., Sternin, H., Melamed, E., and Hochman, A. (1996). Prevention of dopamine-induced cell death by thiol antioxidants: possible implications for treatment of Parkinson's disease. Exp. Neurol. 141, 32-39.

Olanow, C. W., Rascol, O., Hauser, R., Feigin, P. D., Jankovic, J., Lang, A., Langston, W., Melamed, E., Poewe, W., Stocchi, F., and Tolosa, E. (2009). A double-blind, delayed-start trial of rasagiline in Parkinson's disease. $N$. Engl. J. Med. 361, 1268-1278.

Ozsoy, O., Seval-Celik, Y., Hacioglu, G., Yargicoglu, P., Demir, R., Agar, A., and Aslan, M. (2011). The influence and the mechanism of docosahexaenoic acid on a mouse model of Parkinson's disease. Neurochem. Int 59, 664-670.

Palacios, N., Weisskopf, M., Simon, K., Gao, X., Schwarzschild, M., and Ascherio, A. (2010). Polymorphisms of caffeine metabolism and estrogen receptor genes and risk of
Parkinson's disease in men and women. Parkinsonism Relat. Disord. 16, 370-375.

Paraskevas, G. P., Kapaki, E., Petropoulou, O., Anagnostouli, M., Vagenas, V., and Papageorgiou, C. (2003). Plasma levels of antioxidant vitamins $\mathrm{C}$ and $\mathrm{E}$ are decreased in vascular parkinsonism. J. Neurol. Sci. 215, 51-55.

Pearce, R. K., Owen, A., Daniel, S., Jenner, P., and Marsden, C. D. (1997). Alterations in the distribution of glutathione in the substantia nigra in Parkinson's disease. J. Neural Transm. 104, 661-677.

Perlmutter, J. S. (1988). New insights into the pathophysiology of Parkinson's disease: the challenge of positron emission tomography. Trends Neurosci. 11, 203-208.

Perry, T., and Greig, N. H. (2005). Enhancing central nervous system endogenous GLP-1 receptor pathways for intervention in Alzheimer's disease. Curr. Alzheimer Res. 2, 377-385.

Perry, T., Holloway, H. W., Weerasuriya, A., Mouton, P. R., Duffy, K., Mattison, J. A., and Greig, N. H. (2007). Evidence of GLP-1-mediated neuroprotection in an animal model of pyridoxine-induced peripheral sensory neuropathy. Exp. Neurol. 203 293-301.

Perry, T., Lahiri, D. K., Chen, D., Zhou, J., Shaw, K. T., Egan, J. M., and Greig, N. H. (2002). A novel neurotrophic property of glucagon-like peptide 1 : a promoter of nerve growth factormediated differentiation in PC12 cells. J. Pharmacol. Exp. Ther. 300, 958-966.

Perry, T. L., Godin, D. V., and Hansen, S. (1982). Parkinson's disease: a disorder due to nigral glutathione deficiency? Neurosci. Lett. 33, 305-310.

Perry, T. L., Yong, V. W., Clavier, R. M., Jones, K., Wright, J. M., Foulks, J. G., and Wall, R. A. (1985). Partial protection from the dopaminergic neurotoxin N-methyl-4-phenyl1,2,3,6-tetrahydropyridine by four different antioxidants in the mouse. Neurosci. Lett. 60, 109-114.

Perry, T. L., Yong, V. W., Hansen, S., Jones, K., Bergeron, C., Foulks, J. G., and Wright, J. M. (1987). Alphatocopherol and beta-carotene do not protect marmosets against the dopaminergic neurotoxicity of N-methyl-4-phenyl-1,2,3,6tetrahydropyridine. J. Neurol. Sci. 81, 321-331. 
Pileblad, E., Magnusson, T., and Fornstedt, B. (1989). Reduction of brain glutathione by L-buthionine sulfoximine potentiates the dopamine-depleting action of 6-hydroxydopamine in rat striatum. J. Neurochem. 52, 978-980.

Pizzi, M., Ribola, M., Valerio, A., Memo, M., and Spano, P. (1991). Various $\mathrm{Ca} 2+$ entry blockers prevent glutamate-induced neurotoxicity. Eur. J. Pharmacol. 209, 169-173.

Powers, H. J. (1987). A study of maternofetal iron transfer in the riboflavin-deficient rat. J. Nutr. 117 852-856.

Powers, H. J. (2003). Riboflavin (vitamin B-2) and health. Am. J. Clin. Nutr. 77, 1352-1360.

Powers, H. J., Bates, C. J., and Duerden, J. M. (1983). Effects of riboflavin deficiency in rats on some aspects of iron metabolism. Int. J. Vitam. Nutr. Res. $53,371-376$

Prediger, R. D. (2010). Effects of caffeine in Parkinson's disease: from neuroprotection to the management of motor and non-motor symptoms. $J$. Alzheimers Dis. 20(Suppl. 1), S205S220.

Quick, M. (2004). Smoking, nicotine and Parkinson's disease. Trends Neurosci. $27,561-568$.

Quik, M., and Jeyarasasingam, G. (2000). Nicotinic receptors and Parkinson's disease. Eur. J. Pharmacol. 393, 223-230.

Quik, M., Parameswaran, N., McCallum, S. E., Bordia, T., Bao, S., McCormack, A., Kim, A., Tyndale, R. F., Langston, J. W., and Di Monte, D. A. (2006). Chronic oral nicotine treatment protects against striatal degeneration in MPTPtreated primates. J. Neurochem. 98, 1866-1875.

Quintero, E. M., Willis, L., Singleton, R., Harris, N., Huang, P., Bhat, N., and Granholm, A. C. (2006). Behavioral and morphological effects of minocycline in the 6-hydroxydopamine rat model of Parkinson's disease. Brain Res. 1093, 198-207.

Radad, K., Moldzio, R., and Rausch, W. D. (2010). Minocycline protects dopaminergic neurons against longterm rotenone toxicity. Can. J. Neurol. Sci. 37, 81-85.

Rascol, O., Fitzer-Attas, C. J., Hauser, R., Jankovic, J., Lang, A., Langston, J. W., Melamed, E., Poewe, W., Stocchi, F., Tolosa, E., Eyal, E., Weiss, Y. M., and Olanow, C. W. (2011). A double-blind, delayed-start trial of rasagiline in Parkinson's disease (the ADAGIO study): prespecified and post-hoc analyses of the need for additional therapies, changes in UPDRS scores, and nonmotor outcomes. Lancet Neurol. 10, 415-423.

Ravina, B. M., Fagan, S. C., Hart, R. G., Hovinga, C. A., Murphy, D. D., Dawson, T. M., and Marler, J. R. (2003). Neuroprotective agents for clinical trials in Parkinson's disease: a systematic assessment. Neurology 60 , 1234-1240.

Reiter, R. J., Carneiro, R. C., and Oh, C. S. (1997). Melatonin in relation to cellular antioxidative defense mechanisms. Horm. Metab. Res. 29, 363-372.

Ren, Y. R., Nishida, Y., Yoshimi, K., Yasuda, T., Jishage, K., Uchihara, T., Yokota, T., Mizuno, Y., and Mochizuki, H. (2006). Genetic vitamin E deficiency does not affect MPTP susceptibility in the mouse brain. J. Neurochem. 98, 1810-1816.

Ricciarelli, R., Argellati, F., Pronzato, M. A., and Domenicotti, C. (2007). Vitamin $\mathrm{E}$ and neurodegenerative diseases. Mol. Aspects Med. 28, 591-606.

Riederer, P., Sofic, E., Rausch, W. D., Schmidt, B., Reynolds, G. P., Jellinger, K., and Youdim, M. B. (1989). Transition metals, ferritin, glutathione, and ascorbic acid in parkinsonian brains. J. Neurochem. 52, 515-520.

Rocchitta, G., Migheli, R., Esposito, G., Marchetti, B., Desole, M. S., Miele, E., and Serra, P. A. (2006). Endogenous melatonin protects L-DOPA from autoxidation in the striatal extracellular compartment of the freely moving rat: potential implication for long-term L-DOPA therapy in Parkinson's disease. J. Pineal Res. 40, 204-213.

Roghani, M., and Behzadi, G. (2001). Neuroprotective effect of vitamin E on the early model of Parkinson's disease in rat: behavioral and histochemical evidence. Brain Res. 892, 211-217.

Ross, G. W., Abbott, R. D., Petrovitch, H., Morens, D. M., Grandinetti, A., Tung, K. H., Tanner, C. M., Masaki, K. H., Blanchette, P. L., Curb, J. D., Popper, J. S., and White, L. R. (2000). Association of coffee and caffeine intake with the risk of Parkinson disease. JAMA 283, 2674-2679.

Ryan, M. E., and Ashley, R. A. (1998). How do tetracyclines work? Adv. Dent. Res. 12, 149-151.

Ryan, M. E., Ramamurthy, N. S., and Golub, L. M. (1998). Tetracyclines inhibit protein glycation in experimental diabetes. Adv. Dent. Res. 12, 152-158.

Saaksjarvi, K., Knekt, P., Rissanen, H., Laaksonen, M. A., Reunanen, A., and Mannisto, S. (2008). Prospective study of coffee consumption and risk of Parkinson's disease. Eur. J. Clin. Nutr. 62, 908-915.

Sagi, Y., Weinreb, O., Weinstock, M., and Youdim, M. B. (2001). Neuroprotective and neurorescue properties of rasagiline and TV3326 in MPTP model of Parkinson's disease. Neural Plast. 8, 197-198.

Saini, T., Bagchi, M., Bagchi, D., Jaeger S., Hosoyama, S., and Stohs, S. J. (1998). Protective ability of acetylsalicylic acid (aspirin) to scavenge radiation induced free radicals in J774A.1 macrophage cells. Res Commun. Mol. Pathol. Pharmacol. 101, 259-268.

Sairam, K., Saravanan, K. S., Banerjee, R., and Mohanakumar, K. P. (2003). Non-steroidal anti-inflammatory drug sodium salicylate, but not diclofenac or celecoxib, protects against 1-methyl-4-phenyl pyridinium-induced dopaminergic neurotoxicity in rats. Brain Res. 966 245-252.

Sakamoto, T., Cansev, M., and Wurtman, R. J. (2007). Oral supplementation with docosahexaenoic acid and uridine- $5^{\prime}$-monophosphate increases dendritic spine density in adult gerbil hippocampus. Brain Res. 1182, 50-59.

Salem, N. Jr., Litman, B., Kim, H. Y., and Gawrisch, K. (2001). Mechanisms of action of docosahexaenoic acid in the nervous system. Lipids 36 , 945-959.

Samadi, P., Gregoire, L., Rouillard, C., Bedard, P. J., Di Paolo, T., and Levesque, D. (2006). Docosahexaenoic acid reduces levodopa-induced dyskinesias in 1-methyl-4-phenyl-1,2,3,6tetrahydropyridine monkeys. Ann Neurol. 59, 282-288.

Samii, A., Etminan, M., Wiens, M. O. and Jafari, S. (2009). NSAID use and the risk of Parkinson's disease: systematic review and meta-analysis of observational studies. Drugs Aging 26, 769-779.

Sandyk, R. (1990). Mechanisms of action of ECT in Parkinson's disease: possible role of pineal melatonin. Int. J. Neurosci. 50, 83-94.

Sato, Y., Kikuyama, M., and Oizumi, K. (1997). High prevalence of vitamin D deficiency and reduced bone mass in Parkinson's disease. Neurology 49, 1273-1278.

Sautter, J., Kupsch, A., Earl, C. D., and Oertel, W. H. (1997). Degeneration of pre-labelled nigral neurons induced by intrastriatal 6hydroxydopamine in the rat: behavioural and biochemical changes and pretreatment with the calcium-entry blocker nimodipine. Exp. Brain Res. 117, 111-119.

Scheider, W. L., Hershey, L. A., Vena, J. E., Holmlund, T., Marshall, J. R., and Freudenheim, J. L. (1997). Dietary antioxidants and other dietary factors in the etiology of Parkinson's disease. Mov. Disord. 12, 190-196.

Scherzer, C. R., Eklund, A. C., Morse, L. J., Liao, Z., Locascio, J. J., Fefer D., Schwarzschild, M. A., Schlossmacher, M. G., Hauser, M. A., Vance, J. M., Sudarsky, L. R., Standaert, D. G., Growdon, J. H., Jensen, R. V., and Gullans, S. R. (2007). Molecular markers of early Parkinson's disease based on gene expression in blood. Proc. Natl. Acad. Sci. U.S.A. 104, 955-960.

Schlesinger, I., and Schlesinger, N. (2008). Uric acid in Parkinson's disease. Mov. Disord. 23, 1653-1657.

Schulz, J. B., Lindenau, J., Seyfried, J., and Dichgans, J. (2000). Glutathione, oxidative stress and neurodegeneration. Eur. J. Biochem. 267, 4904-4911.

Schwarzschild, M. A., Schwid, S. R., Marek, K., Watts, A., Lang, A. E., Oakes, D., Shoulson, I., Ascherio, A., Hyson, C., Gorbold, E., Rudolph, A., Kieburtz, K., Fahn, S., Gauger, L., Goetz, C., Seibyl, J., Forrest, M., and Ondrasik, J. (2008). Serum urate as a predictor of clinical and radiographic progression in Parkinson disease. Arch. Neurol. 65, 716-723.

Seaton, T. A., Jenner, P., and Marsden, C. D. (1996). Thioctic acid does not restore glutathione levels or protect against the potentiation of 6 hydroxydopamine toxicity induced by glutathione depletion in rat brain. J. Neural Transm. 103, 315-329.

Shamsuddin, A. M., Vucenik, I., and Cole, K. E. (1997). IP6: a novel anti-cancer agent. Life Sci. 61, 343-354.

Sharma, S., Kheradpezhou, M., Shavali, S., El Refaey, H., Eken, J., Hagen, C., and Ebadi, M. (2004). Neuroprotective actions of coenzyme Q10 in Parkinson's disease. Meth. Enzymol. 382, 488-509.

Shults, C. W. (2003). Coenzyme Q10 in neurodegenerative diseases. Curr. Med. Chem. 10, 1917-1921.

Shults, C. W., Flint Beal, M., Song, D., and Fontaine, D. (2004). Pilot trial of high dosages of coenzyme Q10 in patients with Parkinson's disease. Exp. Neurol. 188, 491-494.

Shults, C. W., Haas, R. H., and Beal, M. F. (1999). A possible role of coenzyme Q10 in the etiology and treatment of Parkinson's disease. Biofactors 9, 267-272. 
Shults, C. W., Haas, R. H., Passov, D., and Beal, M. F. (1997). Coenzyme Q10 levels correlate with the activities of complexes I and II/III in mitochondria from parkinsonian and nonparkinsonian subjects. Ann. Neurol. 42, 261-264.

Shults, C. W., Oakes, D., Kieburtz, K., Beal, M. F., Haas, R., Plumb, S., Juncos, J. L., Nutt, J., Shoulson, I., Carter, J., Kompoliti, K., Perlmutter, J. S., Reich, S., Stern, M., Watts, R. L., Kurlan, R., Molho, E., Harrison, M., and Lew, M. (2002). Effects of coenzyme Q10 in early Parkinson disease: evidence of slowing of the functional decline. Arch. Neurol. 59, 1541-1550.

Sian, J., Dexter, D. T., Lees, A. J., Daniel, S., Agid, Y., Javoy-Agid, F., Jenner, P., and Marsden, C. D. (1994). Alterations in glutathione levels in Parkinson's disease and other neurodegenerative disorders affecting basal ganglia. Ann. Neurol. $36,348-355$.

Simon, K. C., Chen, H., Gao, X., Schwarzschild, M. A., and Ascherio, A. (2009). Reproductive factors, exogenous estrogen use, and risk of Parkinson's disease. Mov. Disord. 24, 1359-1365.

Simuni, T., Borushko, E., Avram, M. J., Miskevics, S., Martel, A., Zadikoff, C., Videnovic, A., Weaver, F. M., Williams, K., and Surmeier, D. J. (2010). Tolerability of isradipine in early Parkinson's disease: a pilot dose escalation study. Mov. Disord. 25, 2863-2866.

Singh, S., Singh, K., Patel, S., Patel, D. K., Singh, C., Nath, C., and Singh, M. P. (2008). Nicotine and caffeinemediated modulation in the expression of toxicant responsive genes and vesicular monoamine transporter2 in 1-methyl 4-phenyl-1,2,3,6tetrahydropyridine-induced Parkinson's disease phenotype in mouse. Brain Res. 1207, 193-206.

Sirivech, S., Driskell, J., and Frieden, E. (1977). NADH-FMN oxidoreductase activity and iron content of organs from riboflavin and irondeficient rats. J. Nutr. 107, 739-745.

Smith, M. P., Fletcher-Turner, A., Yurek, D. M., and Cass, W. A. (2006). Calcitriol protection against dopamine loss induced by intracerebroventricular administration of 6hydroxydopamine. Neurochem. Res. 31, 533-539.

Sohmiya, M., Tanaka, M., Tak, N. W., Yanagisawa, M., Tanino, Y., Suzuki, Y., Okamoto, K., and Yamamoto, Y. (2004). Redox status of plasma coenzyme Q10 indicates elevated systemic oxidative stress in Parkinson's disease. J. Neurol. Sci. 223, 161-166.
Speiser, Z., Mayk, A., Eliash, S., and Cohen, S. (1999). Studies with rasagiline, a MAO-B inhibitor, in experimental focal ischemia in the rat. $J$. Neural Transm. 106, 593-606.

Sriram, K., Miller, D. B., and O'Callaghan, J. P. (2006). Minocycline attenuates microglial activation but fails to mitigate striatal dopaminergic neurotoxicity: role of tumor necrosis factor-alpha. $J$. Neurochem. 96, 706-718.

Takeuchi, H., Yanagida, T., Inden, M., Takata, K., Kitamura, Y., Yamakawa, K., Sawada, H., Izumi, Y., Yamamoto, N., Kihara, T., Uemura, K., Inoue, H., Taniguchi, T., Akaike, A., Takahashi, R., and Shimohama, S. (2009). Nicotinic receptor stimulation protects nigral dopaminergic neurons in rotenone-induced Parkinson's disease models. J. Neurosci. Res. 87, 576-585.

Tan, E. K., Tan, C., Fook-Chong, S. M., Lum, S. Y., Chai, A., Chung, H., Shen, H., Zhao, Y., Teoh, M. L., Yih, Y., Pavanni, R., Chandran, V. R., and Wong, M. C. (2003). Dosedependent protective effect of coffee, tea, and smoking in Parkinson's disease: a study in ethnic Chinese. J. Neurol. Sci. 216, 163-167.

Tapias, V., Cannon, J. R., and Greenamyre, J. T. (2010). Melatonin treatment potentiates neurodegeneration in a rat rotenone Parkinson's disease model. J. Neurosci. Res. 88, 420-427.

Tappel, A. (1962). Vitamin E as the biological lipid antioxidant. Vitam. Horm. 20, 493-509.

Tarnopolsky, M. A., and Beal, M. F. (2001). Potential for creatine and other therapies targeting cellular energy dysfunction in neurological disorders. Ann. Neurol. 49, 561-574.

Tatton, W., Chalmers-Redman, R., and Tatton, N. (2003). Neuroprotection by deprenyl and other propargylamines: glyceraldehyde-3phosphate dehydrogenase rather than monoamine oxidase B. $J$. Neural Transm. 110, 509-515.

Tikka, T., Fiebich, B. L., Goldsteins, G., Keinanen, R., and Koistinaho, J. (2001). Minocycline, a tetracycline derivative, is neuroprotective against excitotoxicity by inhibiting activation and proliferation of microglia. J. Neurosci. 21, 2580-2588.

Tohgi, H., Abe, T., Takahashi, S., and Kikuchi, T. (1993). The urate and xanthine concentrations in the cerebrospinal fluid in patients with vascular dementia of the Binswanger type, Alzheimer type dementia, and Parkinson's disease. J. Neural Transm. Park. Dis. Dement. Sect. 6, 119-126.
Ton, T. G., Heckbert, S. R., Longstreth, W. T. Jr., Rossing, M. A., Kukull, W. A., Franklin, G. M., Swanson, P. D., Smith-Weller, T., and Checkoway, H. (2006). Nonsteroidal antiinflammatory drugs and risk of Parkinson's disease. Mov. Disord. 21, 964-969.

Toulorge, D., Guerreiro, S., Hild, A., Maskos, U., Hirsch, E. C., and Michel, P. P. (2011). Neuroprotection of midbrain dopamine neurons by nicotine is gated by cytoplasmic Ca2+. FASEB J. 25, 2563-2573.

Traber, M. G., and Sies, H. (1996). Vitamin E in humans: demand and delivery. Annu. Rev. Nutr. 16, 321-347.

Trinh, K., Andrews, L., Krause, J., Hanak, T., Lee, D., Gelb, M., and Pallanck, L. (2010). Decaffeinated coffee and nicotine-free tobacco provide neuroprotection in Drosophila models of Parkinson's disease through an NRF2-dependent mechanism. $J$. Neurosci. 30, 5525-5532.

van den Pol, A. N. (1986). Tyrosine hydroxylase immunoreactive neurons throughout the hypothalamus receive glutamate decarboxylase immunoreactive synapses: a double pre-embedding immunocytochemical study with particulate silver and HRP. J. Neurosci. 6 , 877-891.

Wahner, A. D., Bronstein, J. M., Bordelon, Y. M., and Ritz, B. (2007). Nonsteroidal anti-inflammatory drugs may protect against Parkinson disease. Neurology 69, 1836-1842.

Wang, J. Y., Wu, J. N., Cherng, T. L., Hoffer, B. J., Chen, H. H. Borlongan, C. V., and Wang, Y. (2001). Vitamin D(3) attenuates 6hydroxydopamine-induced neurotoxicity in rats. Brain Res. 904, 67-75.

Wang, X., Zhao, X., Mao, Z. Y., Wang, X. M., and Liu, Z. L. (2003). Neuroprotective effect of docosahexaenoic acid on glutamate-induced cytotoxicity in rat hippocampal cultures. Neuroreport 14, 2457-2461.

Weinreb, O., Bar-Am, O., Amit, T., Chillag-Talmor, O., and Youdim, M. B. (2004). Neuroprotection via prosurvival protein kinase $\mathrm{C}$ isoforms associated with Bcl-2 family members. FASEB J. 18, 1471-1473.

Wu, A., Ying, Z., and Gomez-Pinilla, F. (2004). Dietary omega-3 fatty acids normalize BDNF levels, reduce oxidative damage, and counteract learning disability after traumatic brain injury in rats. J. Neurotrauma 21, 1457-1467.

Wu, D. C., Jackson-Lewis, V., Vila, M., Tieu, K., Teismann, P., Vadseth, C., Choi, D. K., Ischiropoulos, H., and Przedborski, S. (2002). Blockade of microglial activation is neuroprotective in the 1-methyl-4phenyl-1,2,3,6-tetrahydropyridine mouse model of Parkinson disease. J. Neurosci. 22, 1763-1771.

Wullner, U., Loschmann, P. A., Schulz, J. B., Schmid, A., Dringen, R., Eblen, F., Turski, L., and Klockgether, T. (1996). Glutathione depletion potentiates MPTP and MPP+ toxicity in nigral dopaminergic neurones. Neuroreport 7, 921-923.

Wurtman, R. J., Ulus, I. H., Cansev, M., Watkins, C. J., Wang, L., and Marzloff, G. (2006). Synaptic proteins and phospholipids are increased in gerbil brain by administering uridine plus docosahexaenoic acid orally. Brain Res. 1088, 83-92.

Xu, C. J., Klunk, W. E., Kanfer, J. N., Xiong, Q., Miller, G., and Pettegrew, J. W. (1996). Phosphocreatinedependent glutamate uptake by synaptic vesicles. A comparison with atp-dependent glutamate uptake. $J$. Biol. Chem. 271, 13435-13440.

$\mathrm{Xu}, \mathrm{K} ., \mathrm{Xu}, \mathrm{Y}$., Brown-Jermyn, D., Chen, J. F., Ascherio, A., Dluzen, D. E., and Schwarzschild, M. A. (2006). Estrogen prevents neuroprotection by caffeine in the mouse 1-methyl-4phenyl-1,2,3,6-tetrahydropyridine model of Parkinson's disease. $J$. Neurosci. 26, 535-541.

$\mathrm{Xu}, \mathrm{K} ., \mathrm{Xu}, \mathrm{Y} . \mathrm{H}$., Chen, J. F., and Schwarzschild, M. A. (2002). Caffeine's neuroprotection against 1-methyl-4-phenyl-1,2,3,6tetrahydropyridine toxicity shows no tolerance to chronic caffeine administration in mice. Neurosci. Lett. 322, 13-16.

Xu, K., Xu, Y. H., Chen, J. F., and Schwarzschild, M. A. (2010). Neuroprotection by caffeine: time course and role of its metabolites in the MPTP model of Parkinson's disease. Neuroscience 167, 475-481.

Xu, Q., Kanthasamy, A. G., and Reddy, M. B. (2008). Neuroprotective effect of the natural iron chelator, phytic acid in a cell culture model of Parkinson's disease. Toxicology 245, 101-108.

Xu, Q., Kanthasamy, A. G., and Reddy, M. B. (2011). Phytic acid protects against 6-hydroxydopamineinduced dopaminergic neuron apoptosis in normal and iron excess conditions in a cell culture model. Parkinsons Dis. 2011, 431068.

Yang, L., Calingasan, N. Y., Wille, E. J., Cormier, K., Smith, K., Ferrante, R. J., and Beal, M. F. (2009). Combination therapy with coenzyme Q10 and creatine produces additive neuroprotective effects in models of Parkinson's and Huntington's diseases. J. Neurochem. 109, 1427-1439. 
Yang, L., Sugama, S., Chirichigno, J. W., Gregorio, J., Lorenzl, S., Shin, D. H., Browne, S. E., Shimizu, Y., Joh, T. H., Beal, M. F., and Albers, D. S. (2003). Minocycline enhances MPTP toxicity to dopaminergic neurons. $J$. Neurosci. Res. 74, 278-285.

Yavin, E., Brand, A., and Green, P. (2002). Docosahexaenoic acid abundance in the brain: a biodevice to combat oxidative stress. Nutr. Neurosci. 5, 149-157.

Yogev-Falach, M., Amit, T., Bar-Am, O., and Youdim, M. B. (2003). The importance of propargylamine moiety in the anti-Parkinson drug rasagiline and its derivatives in MAPK-dependent amyloid precursor protein processing. FASEB J. 17, 2325-2327.

Yokota, T., Igarashi, K., Uchihara, T., Jishage, K., Tomita, H., Inaba, A., Li, Y., Arita, M., Suzuki, H., Mizusawa, H., and Arai, H. (2001). Delayedonset ataxia in mice lacking alphatocopherol transfer protein: model for neuronal degeneration caused by chronic oxidative stress. Proc. Natl. Acad. Sci. U.S.A. 98, 15185-15190.

Yong, V. W., Perry, T. L., and Krisman, A. A. (1986). Depletion of glutathione in brainstem of mice caused by N-methyl-4-phenyl1,2,3,6-tetrahydropyridine is prevented by antioxidant pretreatment. Neurosci. Lett. 63, 56-60.

Youdim, M. B., Amit, T., FalachYogev, M., Bar Am, O., Maruyama, W., and Naoi, M. (2003). The essentiality of Bcl-2, PKC and proteasome-ubiquitin complex activations in the neuroprotectiveantiapoptotic action of the antiParkinson drug, rasagiline. Biochem. Pharmacol. 66, 1635-1641.

Youdim, M. B., Gross, A., and Finberg, J. P. (2001a). Rasagiline [N-propargyl-1R(+)-aminoindan], a selective and potent inhibitor of mitochondrial monoamine oxidase B. Br. J. Pharmacol. 132, 500-506.

Youdim, M. B., Wadia, A., Tatton, W., and Weinstock, M. (2001b). The anti-Parkinson drug rasagiline and its cholinesterase inhibitor derivatives exert neuroprotection unrelated to MAO inhibition in cell culture and in vivo. Ann. N. Y. Acad. Sci. 939, 450-458.

Youdim, M. B., and Weinstock, M. (2001). Molecular basis of neuroprotective activities of rasagiline and the anti-Alzheimer drug TV3326
[(N-propargyl-(3R)aminoindan-5YL)-ethyl methyl carbamate]. Cell. Mol. Neurobiol. 21, 555-573.

Yrjanheikki, J., Keinanen, R., Pellikka, M., Hokfelt, T., and Koistinaho, J. (1998). Tetracyclines inhibit microglial activation and are neuroprotective in global brain ischemia Proc. Natl. Acad. Sci. U.S.A. 95, 15769-15774.

Yu, Z. F., Bruce-Keller, A. J., Goodman, Y., and Mattson, M. P. (1998). Uric acid protects neurons against excitotoxic and metabolic insults in cell culture, and against focal ischemic brain injury in vivo. J. Neurosci. Res. 53, 613-625.

Zhang, S. M., Hernan, M. A., Chen, H. Spiegelman, D., Willett, W. C., and Ascherio, A. (2002). Intakes of vitamins $\mathrm{E}$ and $\mathrm{C}$, carotenoids, vitamin supplements, and PD risk. Neurology 59, 1161-1169.

Zhao, C., Ling, Z., Newman, M. B., Bhatia, A., and Carvey, P. M. (2007) TNF-alpha knockout and minocycline treatment attenuates bloodbrain barrier leakage in MPTPtreated mice. Neurobiol. Dis. 26, 36-46.

Zhou, W., Bercury, K., Cummiskey, J. Luong, N., Lebin, J., and Freed, C. R.
(2011). Phenylbutyrate up-regulates the DJ-1 protein and protects neurons in cell culture and in animal models of Parkinson disease. J. Biol. Chem. 286, 14941-14951.

Conflict of Interest Statement: The authors declare that the research was conducted in the absence of any commercial or financial relationships that could be construed as a potential conflict of interest.

Received: 12 September 2011; paper pending published: 10 October 2011; accepted: 21 October 2011; published online: 21 November 2011.

Citation: Seidl SE and Potashkin JA (2011) The promise of neuroprotective agents in Parkinson's disease. Front. Neur. 2:68. doi: 10.3389/fneur.2011.00068 This article was submitted to Frontiers in Neuropharmacology, a specialty of Frontiers in Neurology.

Copyright (c) 2011 Seidl and Potashkin. This is an open-access article subject to a non-exclusive license between the authors and Frontiers Media SA, which permits use, distribution and reproduction in other forums, provided the original authors and source are credited and other Frontiers conditions are complied with. 